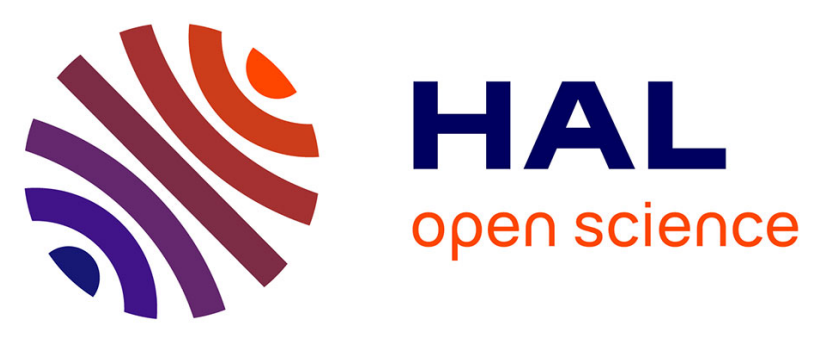

\title{
Caged Glutamates with $\pi$-Extended 1,2-Dihydronaphthalene Chromophore: Design, Synthesis, Two-Photon Absorption Property, and Photochemical Reactivity
}

Srikanth Boinapally, Bo Huang, Manabu Abe, Claudine Katan, Jun Noguchi, Satoshi Watanabe, Haruo Kasai, Bing Xue, Takayoshi Kobayashi

\section{To cite this version:}

Srikanth Boinapally, Bo Huang, Manabu Abe, Claudine Katan, Jun Noguchi, et al.. Caged Glutamates with $\pi$-Extended 1,2-Dihydronaphthalene Chromophore: Design, Synthesis, Two-Photon Absorption Property, and Photochemical Reactivity. Journal of Organic Chemistry, 2014, 79 (17), pp.7822-7830. 10.1021/jo501425p . hal-01061379

\section{HAL Id: hal-01061379 https://hal.science/hal-01061379}

Submitted on 24 Nov 2016

HAL is a multi-disciplinary open access archive for the deposit and dissemination of scientific research documents, whether they are published or not. The documents may come from teaching and research institutions in France or abroad, or from public or private research centers.
L'archive ouverte pluridisciplinaire $\mathbf{H A L}$, est destinée au dépôt et à la diffusion de documents scientifiques de niveau recherche, publiés ou non, émanant des établissements d'enseignement et de recherche français ou étrangers, des laboratoires publics ou privés. 


\section{Caged Glutamates with $\pi$-Extended 1,2- Dihydronaphthalene Chromophore: Design, Synthesis, Two-Photon Absorption Property, and Photochemical Reactivity}

Srikanth Boinapally, ${ }^{\dagger, \vec{*}}$ Bo Huang, ${ }^{\dagger}$ Manabu Abe, $,{ }^{\dagger},{ }^{\dagger,}$ Claudine Katan, ${ }^{,}$, Jun Noguchi,,$/ /$Satoshi Watanabe, ${ }^{\ddagger, / /}$ Haruo Kasai, ${ }^{\ddagger}, /$ Bing Xue, ${ }^{\ddagger, \perp}$ and Takayoshi Kobayashi ${ }^{\ddagger, \perp}$

${ }^{\dagger}$ Department of Chemistry, Graduate School of Science, Hiroshima University (HIRODAI), 1-3-1 Kagamiyama, Higashi-Hiroshima, Hiroshima 739-8526, Japan ‡JST-CREST, Gobancho 7 K’s Gabancho, Chiyodaku, Tokyo 102-0075, Japan ${ }^{\S}$ Institut des Sciences Chimiques de Rennes, UMR 6226 CNRS-Université Rennes 1, 35042 Rennes, France

" Laboratory of Structural Physiology, CDBIM, Graduate School of Medicine, The University of Tokyo, Bunkyo-ku, Tokyo 113-0033, Japan

${ }^{\perp}$ Advanced Ultrafast Laser Research Center, The University of Electro-Communications, Chofugaoka 1-5-1, Chofu, Tokyo 182-8585, Japan

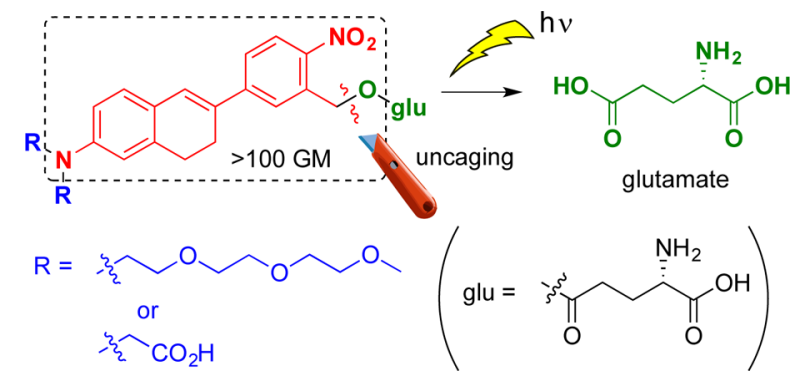

ABSTRACT: Caging and photochemical uncaging of the excitatory neurotransmitter L-glutamate (glu) offers a potentially valuable toolfor understanding the mechanisms of neuronal processes. Designing water-soluble caged glutamates with the appropriate two-photonabsorption property is an attractive strategy to achieve this. Thispaper describes the design, synthesis, and photochemical reactivityof caged glutamates with $\pi$-extended 1,2dihydronaphthalenestructures, which possess a two-photon cross-section of 120 GMand an excellent buffer solubility (up to $115 \mathrm{mM}$ ). High yields up to99\% glutamate were observed in the photolysis of two cagedglutamates. Suzuki-Miyaura cross-coupling and Buchwald-Hartwigamination were used as the key reactions to synthesize the caged compounds. 
POST-PRINT: dx.doi.org/10.1021/jo501425p I J. Org. Chem. 2014, 79, 7822-7830

\section{INTRODUCTION}

Caged compounds are important reagents in physiological studies, particularly in the field of neuroscience. ${ }^{1}$ Spatially and temporally controlled uncaging of neurotransmitters upon photolysis enables a better understanding of in vivo neuronal processes. For example, caged glutamates play a crucial role when studying mammalian learning and memory mechanisms. $^{2}$

In engineering these probes, several well-defined properties of caged compounds must be considered. A fast and efficient uncaging of the biologically active molecule is important under irradiation conditions, and thermal stability of caged com- pounds is required in the physiological environment. However, affording both significant two-photon absorption (TPA) and good water solubility are among the most recent issues for in vivo studies of caged compounds. Using two photon (near-IR) as opposed to one (UV-vis) allows a deeper penetration depth, reduces scattering in biological tissues, and also reduces optical absorption by endogenous chromophores, causing less photo- damage. ${ }^{3}$ Thus, the pertinent molecular design and synthesis of new caged compounds, based on chromophores with a high TPA cross-section $\left(\sigma_{2}\right.$ in GM), remains a challenge.

In the last two decades, several types of caged glutamates such as nitrobenzyl-, 7aminocoumarinyl-, ruthenium biphenyl-, and carboxymethylnitroindolinyl-caged compounds have been designed and synthesized for physiological studies (Figure 1). Examples (including their reported two-photon uncaging cross sections, $\left.\sigma_{2} \Phi_{\mathrm{u}}\right)^{4}$ include $\mathrm{N}$-nitrophenethyloxycarbonyl (Noc- glu), ${ }^{5}$ carboxynitrobenzyl (CNB-glu), ${ }^{6}$ bromohydroxycoumarin (Bhc-glu, $1 \mathrm{GM}^{7} / 740 \mathrm{~nm}$ ), ${ }^{8}$ methoxynitroindolinyl (MNI-glu, $0.06 \mathrm{GM} / 740 \mathrm{~nm}),{ }^{9}$ carboxymethylnitroindolinyl (CDNI-glu, $\left.0.06 \mathrm{GM} / 720 \mathrm{~nm}\right){ }^{10}$ propylmethoxynitrobiphenyl (PMNB-glu, $0.45 \mathrm{GM} / 800 \mathrm{~nm}$ ), ${ }^{11}$ ruthenium bipyridine (RuBi, $0.14 \mathrm{GM} / 800 \mathrm{~nm}$ ), ${ }^{12}$ and bisnitropropylstyrylfluorene (BNSF-glu, 5 GM/800 $\mathrm{nm}) .{ }^{13}$ Recently, we reported the synthesis and photochemical reactivity of caged glutamates with a $\pi$-extended coumarin chromophore (HBC-glu) as a photolabile protecting group. ${ }^{14}$

Herein, we report the design, synthesis, and TPA properties of caged glutamates 4 and 5 with a rigid stilbene-based structure (see Figure 3). Their photochemical release of glutamate was assessed in this study. 


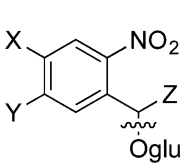

Noc and CNB

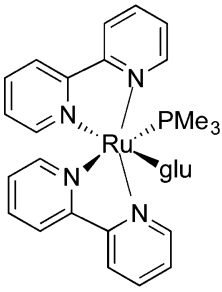

$\mathrm{RuBi}$

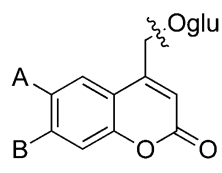

Bhc

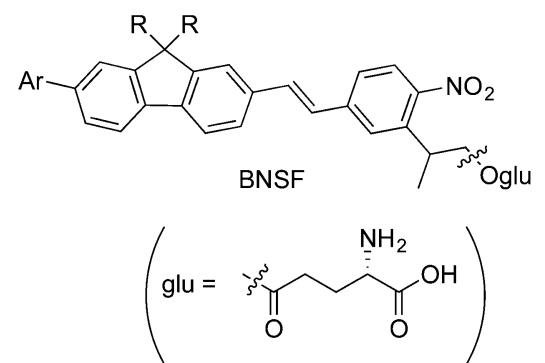

Figure 1. Examples of caged glutamates.

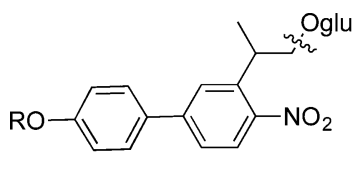

PMNB

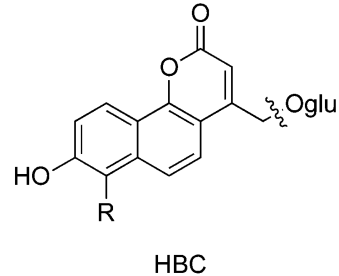

\section{RESULTS AND DISCUSSION}

Molecular Design of High TPA Chromophore with Uncaging Reactivity. Extended $\pi$ conjugated molecules, such as stilbene derivatives, are promising candidates for chromophores with high TPA responses. ${ }^{15,16}$ According to the literature, E-stilbene 1 has a TPA cross-section of $12 \mathrm{GM}$ at $514 \mathrm{~nm} .{ }^{17}$ The corresponding computed value at the INDOMRD-CI level at $27.3 \mathrm{GM}$ at $466 \mathrm{~nm}$ has the same order of magnitude. ${ }^{16}$ The major reactivity of the electronically excited state of stilbenes, i.e., the deactivation process, is the cis-trans isomerization reaction. However, the bond-cleavage reaction from the electronically excited state is indispensable for the uncaging of biologically active compounds upon photolysis. Thus, the simple ring-closed 1,2-dihydronaphthalene structures 2 and 3 were selected to avoid any cis-trans isomerization in the electronically excited state. The nitro group is needed for the uncaging process and the amino group for water solubility. This also adds a push-pull character to the chromophores that is wellknown to favor increased TPA responses. ${ }^{3 \mathrm{k}}$
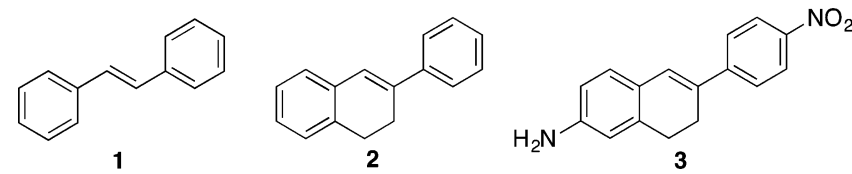

Initially, the one-photon absorption (OPA) and TPA spectra of parent chromophore units 2 and 3, with a 1,2- dihydronaphthalene core, were computed at the TD-B3LYP/ 6$31 \mathrm{G}(\mathrm{d}) / / \mathrm{HF} / 6-31 \mathrm{G}(\mathrm{d})$ theory level in a vacuum (Figure 2). This level of theory has been shown to provide accurate predictions for structure-TPA relationships ${ }^{3 \mathrm{k}}$ Both chromophores led to sizable TPA cross sections $\left(\sigma_{2}\right)$ of $150 \mathrm{GM}$, however, in different spectral regions (Figure 2; and see the Supporting Information for details). In fact, compound 2 had its first TPA maximum at $470 \mathrm{~nm}$, strongly blue-shifted to two times the wavelength of its first OPA maximum (Figure 2a). As expected, due to the push-pull character introduced by the nitro and amino groups, the first TPA maximum of compound 3 was 
significantly red-shifted relative to compound 2, with a good agreement between OPA and TPA maxima. ${ }^{3 \mathrm{k}}$ The computed TPA spectrum of 3 , with a sizable TPA cross-section $\left(\sigma_{2}\right)$ from 600 to $900 \mathrm{~nm}$, prompted us to synthesize the caged glutamates 4 and 5, and investigate their photochemical reactivity (Figure 3).

(a)

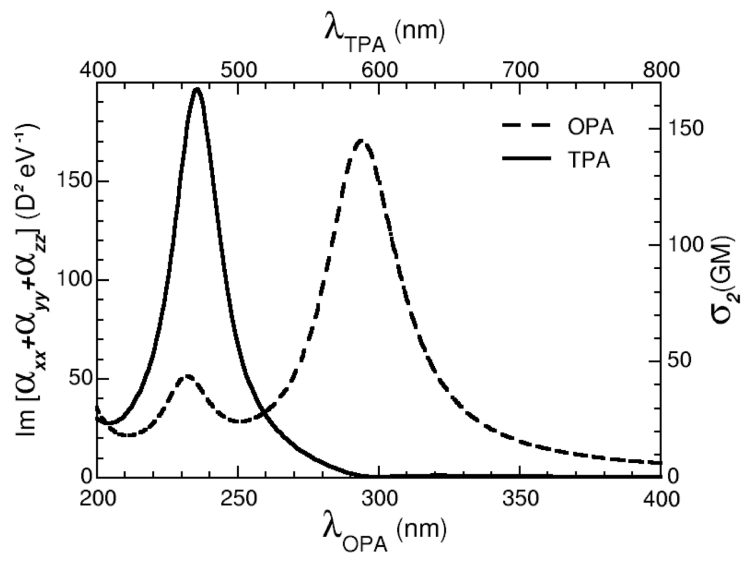

(b)

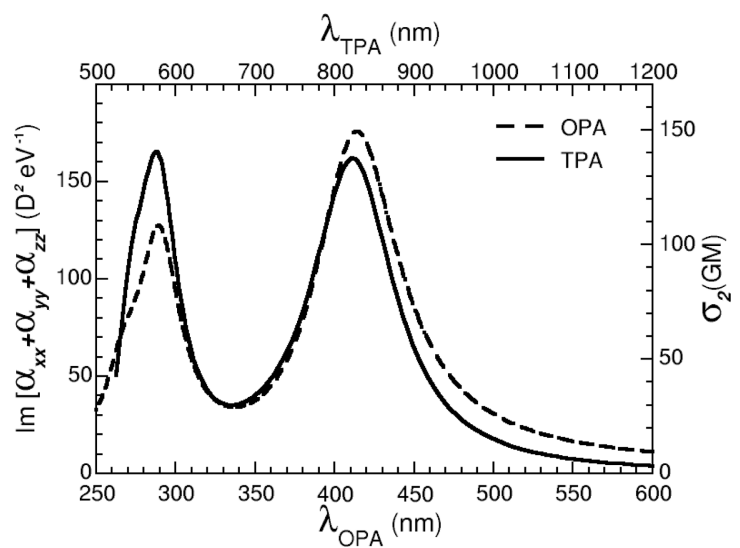

Figure 2. Calculated OPA (dashed lines) and TPA (solid lines) spectra of (a) compound 2 and (b) compound 3 in a vacuum at the TD-B3LYP/6- 31G(d)//HF/6-31G(d) theory level.

Synthesis of Caged Glutamates 4 and 5. Fundamen- tally, compounds 4 and 5 consisted of three units, which included the photolabile protecting group unit (Unit-1) with an onitrophenyl structure and rigid stilbene TPA chromophore; amino groups (Unit-2) with hydrophilic groups, which were an indispensable water solubility unit; and the neurotransmitter glutamic acid (Unit-3). The strategy for the syntheses of caged glutamates 4 and 5 with a rigid stilbene structure is summarized in Figure 3.

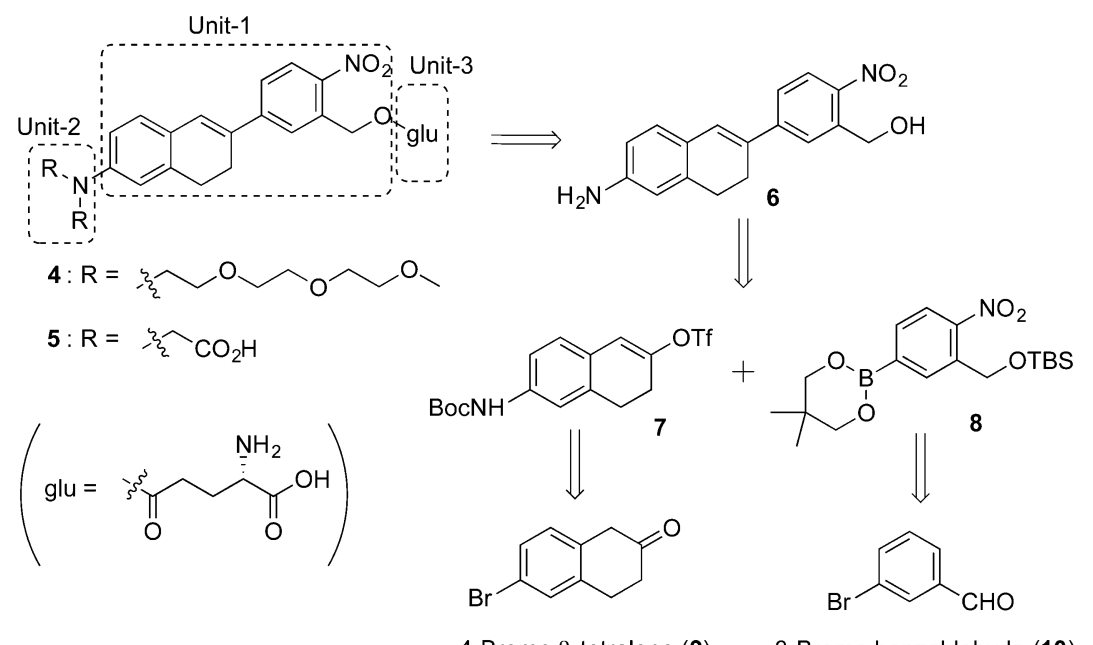

Figure 3. Retrosynthesis of caged glutamates 4 and 5 with a rigid stilbene structure.

Caged compounds 4 and 5 were synthesized from a common intermediate 6 by base- 
mediated bis $\mathrm{N}$-alkylation and the introduction of a glutamate moiety by condensation with the hydroxy terminal. It was anticipated that a Suzuki-Miyaura cross-coupling of enolic triflate 7 with aryl boronate 8 would allow the preparation of the key intermediate 6. Fragments 7 and 8 were obtained from the known 4-bromo-2-tetralone (9) and the commercially available 3 -bromobenzaldehyde (10), respectively.

\section{Scheme $1^{\text {a }}$}

${ }^{a}$ Reagents and conditions: (a) ethylene glycol, p-TSA $\cdot \mathrm{H}_{2} \mathrm{O}, \mathrm{C}_{6} \mathrm{H}_{6}$, reflux, Dean Stark, $6 \mathrm{~h}$,

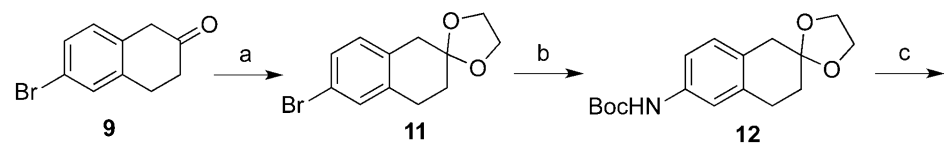
$95 \%$; (b) tert-butyl carbamate, $\mathrm{Cs}_{2} \mathrm{CO}_{3}$,

$\mathrm{Pd}_{2}(\mathrm{dba})_{3}$, xanthphos, dioxane, $100{ }^{\circ} \mathrm{C}, 24 \mathrm{~h}$, $85 \%$; (c) p-TSA $\cdot \mathrm{H}_{2} \mathrm{O}$, acetone, rt, 3 h, $80 \%$; (d) $\mathrm{PhNTf}_{2}$, NaHMDS, THF, $-78^{\circ} \mathrm{C}, 0.5 \mathrm{~h}, 75 \%$.

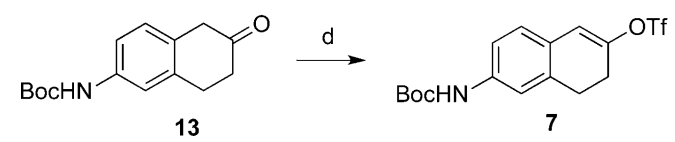

The enolic triflate fragment 7 was synthesized in four steps, starting with 4-bromo-2tetralone $9^{18}$ (Scheme 1). Ketone protection using ethylene glycol in the presence of catalytic p- toluenesulfonic acid (p-TSA) monohydrate afforded 11 in a 95\% yield. The Buchwald amination reaction with tert-butyl carbamate provided 12 in a $85 \%$ yield. ${ }^{19}$ Deprotection of the ethylene ketal moiety was achieved by catalytic usage of p-TSA to furnish 13 in a $80 \%$ yield. Ketone 13 was finally converted to the desired enolic triflate 7 using phenyl trifluoromethane sulfonamide $\left(\mathrm{PhNTf}_{2}\right)$ in a $75 \%$ yield.

\section{Scheme $2^{\mathrm{a}}$}

${ }^{\mathrm{a}}$ Reagents and conditions: (a) $\mathrm{KNO}_{3}, \mathrm{H}_{2} \mathrm{SO}_{4}, 0{ }^{\circ} \mathrm{C}$ to rt, 1 h, 70\%; (b) $\mathrm{NaBH}_{4}, \mathrm{MeOH}, 0{ }^{\circ} \mathrm{C}$ to rt, $15 \mathrm{~min}$, quantitative; (c) TBS-Cl, imidazole, $\mathrm{CH}_{2} \mathrm{Cl}_{2}, 0{ }^{\circ} \mathrm{C}$ to rt, 12 h, 90\%; (d) bis(neopentyl glycolato) diboron, $\mathrm{PdCl}_{2}$ (dppf), $\mathrm{CH}_{3} \mathrm{COOK}, \mathrm{CH}_{3} \mathrm{CN}, 100{ }^{\circ} \mathrm{C}, 1 \mathrm{~h}, 90 \%$.
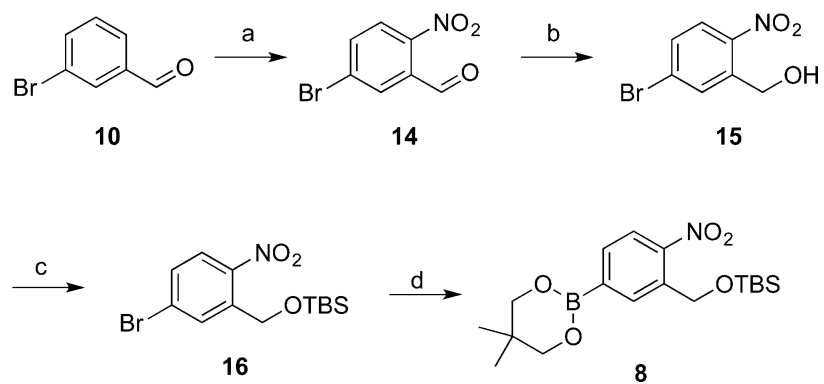

Another fragment, aryl boronate 8, was synthesized from commercially available 3-bromo benzaldehyde (Scheme 2). The aldehyde 10 was subjected to nitration to provide 14 in a $70 \%$ yield, followed by rapid reduction with $\mathrm{NaBH}_{4}$ to furnish the primary alcohol 15 in a quantitative yield. The primary alcohol was protected using tert-butyl dimethylsilyl chloride (TBS-Cl) and imidazole to produce silyl ether 16 in a 90\% yield. Compound 16 was converted to boronate 8 in a $90 \%$ yield using bis(neopentyl glycolato)diboron.

With both enolic triflate 7 and aryl boronate 8 fragments, we coupled the fragments to 
generate the key intermediate 6 (Scheme 3). Accordingly, subjection of enolic triflate 7 to Suzuki-Miyaura cross-coupling ${ }^{20}$ with aryl boronate ester 8 afforded the required skeleton of chromophore 17 in a $85 \%$ yield. The deprotection of both the silyl and tertbutylox- ycarbonyl (Boc) groups was performed using trifluoroacetic acid, resulting in amino alcohol 6 in a $95 \%$ yield.

\section{Scheme $3^{\mathrm{a}}$}

${ }^{\mathrm{a}}$ Reagents and conditions: (a) 8, $\mathrm{PdCl}_{2}$ (dppf), $\mathrm{NEt}_{3}, \mathrm{THF} / \mathrm{H}_{2} \mathrm{O}$ (9:1), reflux, $1 \mathrm{~h}, 85 \%$; (b) TFA, $\mathrm{CH}_{2} \mathrm{Cl}_{2}, 0{ }^{\circ} \mathrm{C}$ to rt, $1 \mathrm{~h}, 95 \%$; (c) 1-bromo- 2-(2-(2methoxyethoxy)ethoxy)ethane or bromo tert-butyl acetate, triisopropylamine, NaI, acetonitrile, reflux, $24 \mathrm{~h}, 75 \%$ for 18 or $80 \%$ for 19 ; (d) ((S)-5-tert-butoxy4-(tert-butoxycarbonylamino)-5oxopenta- noic acid) (22), EDC, DMAP, $\mathrm{CH}_{2} \mathrm{Cl}_{2}, \mathrm{rt}, 24 \mathrm{~h}, 90 \%$ for 20 or $80 \%$ for 21 ; (e) TFA, $\mathrm{CH}_{2} \mathrm{Cl}_{2}, \mathrm{rt}, 5 \mathrm{~h}$, quantitative.
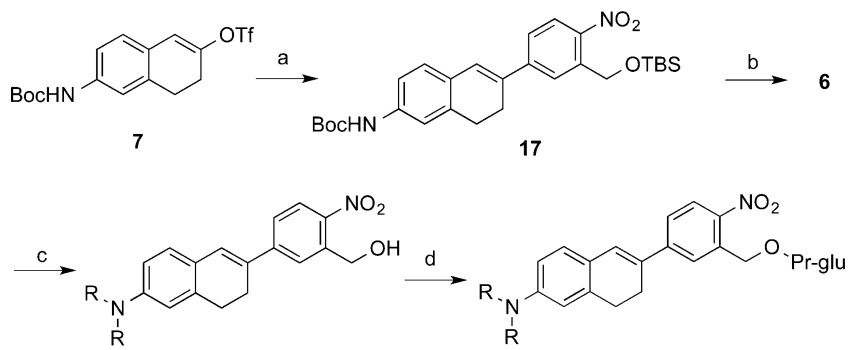

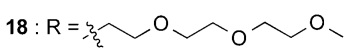
$19: \mathrm{R}=-\xi \hat{\mathrm{z}} \mathrm{CO}_{2} \mathrm{t}-\mathrm{Bu}$

$20: R=$ 多 $21: \mathrm{R}=-\xi \hat{\mathrm{C}} \mathrm{CO}_{2} \mathrm{t}-\mathrm{Bu}$

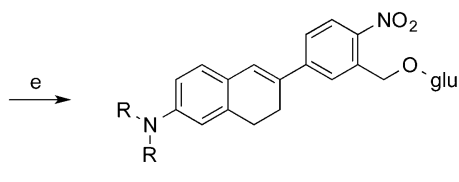

$4: R=$ 多

$5: \mathrm{R}=-\xi \hat{\mathrm{C}} \mathrm{CO}_{2} \mathrm{H}$

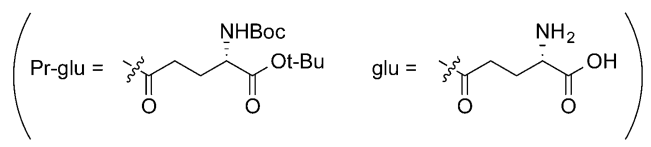

At this stage, water-soluble groups, necessary for biological study, were introduced at the nitrogen terminal. First, treatment of 6 with 1-bromo-2-(2-(2methoxyethoxy)ethoxy)ethane and $\alpha$-bromo tert-butylacetate in the presence of an $\mathrm{N}$ ethyl- diisopropylamine base in acetonitrile produced the bis-alkylated products 18 and 19 in $75 \%$ and $80 \%$ yields, respectively. Finally, the protected glutamic acid Pr-glu ((S)-5tert-butoxy-4- (tert-butoxycarbonylamino)-5-oxopentanoic acid, ${ }^{21} 22$ ) was introduced to cages 18 and 19 to provide glutamate analogues $20\left(\lambda_{\max } 443 \mathrm{~nm}\right.$ in $\mathrm{MeOH}, \varepsilon 29520 \mathrm{M}^{-1}$ $\left.\mathrm{cm}^{-1}\right)$ and $21\left(\lambda_{\max } 420 \mathrm{~nm}\right.$ in $\left.\mathrm{MeOH}, \varepsilon 18377 \mathrm{M}^{-1} \mathrm{~cm}^{-1}\right)$ in $90 \%$ and $80 \%$ yields, respectively. The deprotection of trifluoroacetic acid provided caged glutamates 4 and 5 as TFA salts in quantitative yields. The solubility of 4 and 5 in a HEPES buffer at $\mathrm{pH} 7.4$ was 115 and $35 \mathrm{mM}$, respectively, at room temperature. Both 4 and 5 were thermally stable in a HEPES buffer up to $100{ }^{\circ} \mathrm{C}$.

Photochemical Reactivity of Compounds 20 and 21. The photochemical release of protected glutamic acid 22 from compounds 20 and 21 was investigated by the irradiation of samples (around $10 \mathrm{mM}$ in $\left.\mathrm{CD}_{3} \mathrm{OD}\right)$ using a YAG laser at $355 \mathrm{~nm}(\sim 7 \mathrm{~mJ} /$ pulse) (Figures 4 and 5). The photochemical reaction was monitored using ${ }^{1} \mathrm{H}$ NMR (400 MHz) 
spectroscopic analysis. As shown in Figures 4 and 5, quantitative uncaging of the glutamate unit 22 was proven by comparing the ${ }^{1} \mathrm{H}$ NMR spectrum (Figures $4 \mathrm{c}$ and $5 \mathrm{c}$ ) with the authentic sample of 22 (Figures $4 \mathrm{~d}$ and $5 \mathrm{~d}$ ). The chemical yield of compound 22 after $20 \mathrm{~h}$ irradiation was $>95 \%$ for compound 20 and after $24 \mathrm{~h}$ irradiation was $>99 \%$ for compound 21, using $\mathrm{Ph}_{3} \mathrm{CH}$ as an internal standard in both cases. The quantum yield for the formation of protected glutamic acid 22 from glutamate analogues $20\left(\varepsilon_{355}=5961\right)$ and $21\left(\varepsilon_{355}=5740\right)$ was $\sim 0.01$ at $355 \mathrm{~nm}$ irradiation using Nd:YAG laser $(10 \mathrm{~Hz}, \sim 7 \mathrm{~mJ}$, 4-5 ns pulse-width). The photochemical formation of acetophenone $(\Phi=0.33)$ from valerophenone was used as a chemical actinometer reaction. ${ }^{22}$ Thus, the $\varepsilon_{355} \Phi$ value was calculated as 59.6 and 57.6 for 20 and 21 , respectively.

Synthesis of Parent Compound 23 and Its TPA Spectrum. The photochemically stable compound 23 was synthesized to measure the TPA spectrum (Scheme 4). Enolic triflate 7 was coupled with 4-nitrophenylboronic acid through a Suzuki-Miyaura reaction, using $\mathrm{Pd}\left(\mathrm{PPh}_{3}\right)_{4}$ and $\mathrm{Cs}_{2} \mathrm{CO}_{3}$ and cesium carbonate as a base, leading to the parent core skeleton 23 in a $91 \%$ yield.

The TPA spectrum of the rigid stilbene chromophore $23(11.7 \mathrm{mM})$ is shown in Figure $6 \mathrm{~b}$, together with the OPA spectrum (Figure 6a) in chloroform. The TPA spectrum was measured by nondegenerated absorption between the $800 \mathrm{~nm}$ pump and white light probe beam. A multichannel lock-in amplifier was used for data collection, which provided fine resolution and high signal-to-noise ratio. A TPA value of $\sim 120 \mathrm{GM}$ was observed at 680 $\mathrm{nm}$.

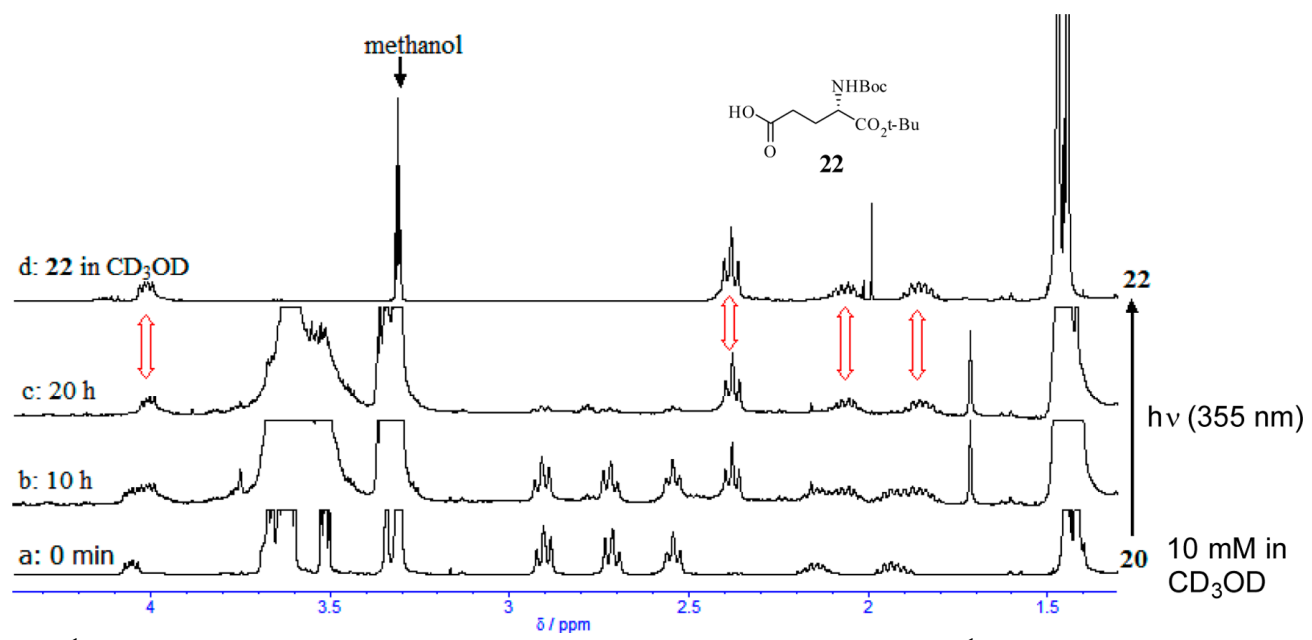

Figure 4. (a) ${ }^{1} \mathrm{H}$ NMR (400 MHz) of compound 20 in $\mathrm{CD}_{3} \mathrm{OD}$; (b) ${ }^{1} \mathrm{H}$ NMR spectrum $(\delta$ 1.4-4.4 ppm) after $10 \mathrm{~h}$ irradiation of 20 using YAG laser $(355 \mathrm{~nm})$ in $\mathrm{CD}_{3} \mathrm{OD}$; (c) ${ }^{1} \mathrm{H}$ NMR spectrum after $20 \mathrm{~h}$ irradiation of 20 in $\mathrm{CD}_{3} \mathrm{OD}$; (d) ${ }^{1} \mathrm{H}$ NMR spectrum of protected glutamic acid 22 in $\mathrm{CD}_{3} \mathrm{OD}$. 
POST-PRINT: dx.doi.org/10.1021/jo501425p | J. Org. Chem. 2014, 79, 7822-7830

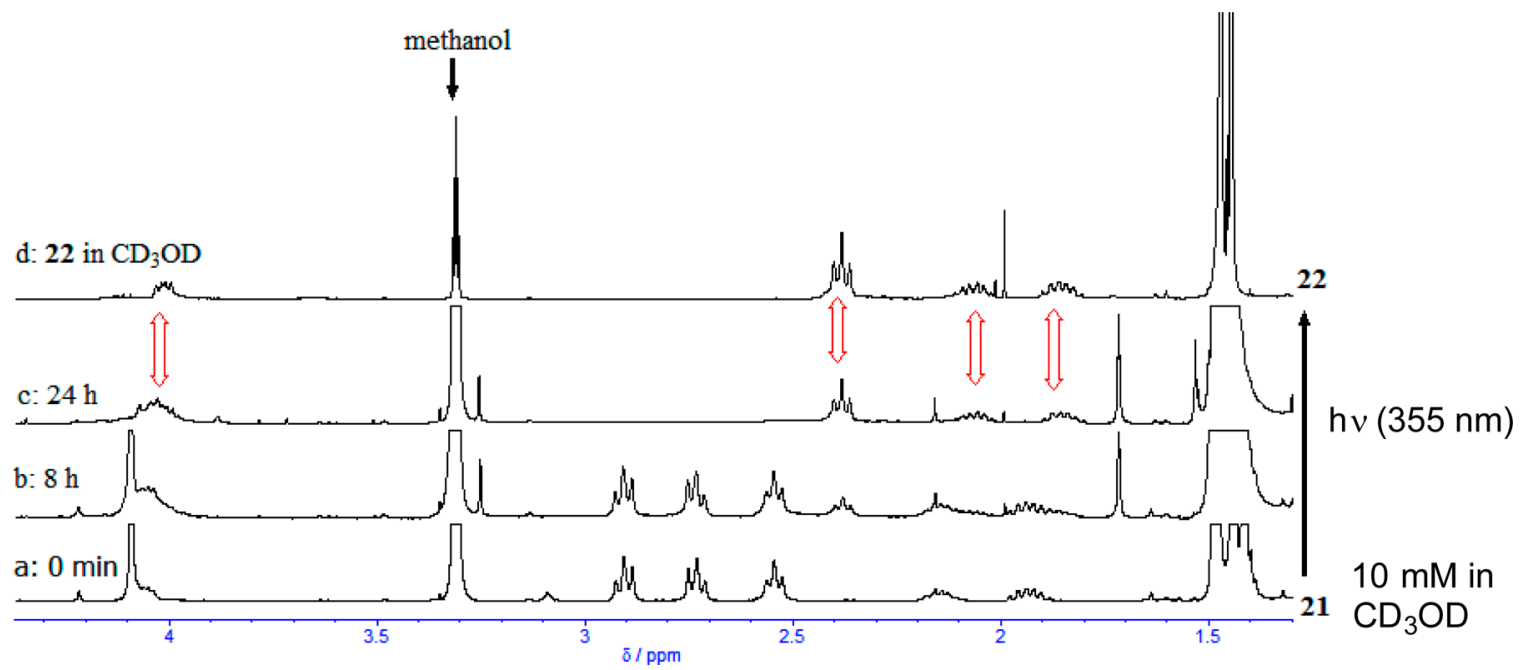

Figure 5. (a) ${ }^{1} \mathrm{H}$ NMR (400 MHz) of compound 21 in $\mathrm{CD}_{3} \mathrm{OD}$; (b) ${ }^{1} \mathrm{H}$ NMR spectrum $(\delta$ 1.4-4.4 $\mathrm{ppm}$ ) after $8 \mathrm{~h}$ irradiation of 21 using YAG laser $(355 \mathrm{~nm})$ in $\mathrm{CD}_{3} \mathrm{OD}$; (c) ${ }^{1} \mathrm{H}$ NMR spectrum after $24 \mathrm{~h}$ irradiation of 21 in $\mathrm{CD}_{3} \mathrm{OD}$; (d) ${ }^{1} \mathrm{H}$ NMR spectrum of protected glutamic acid 22 in $\mathrm{CD}_{3} \mathrm{OD}$.

\section{Scheme 4. Synthesis of Compound 23 for}

\section{Measuring the TPA Spectrum}<smiles>CCCCOc1ccc2c(c1)CCC(OC(=O)OCc1ccccc1)=C2</smiles>

7

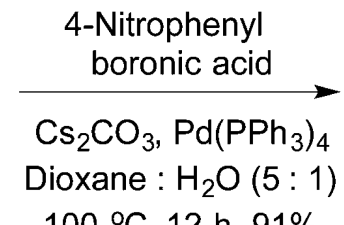

$100{ }^{\circ} \mathrm{C}, 12 \mathrm{~h}, 91 \%$

(a)

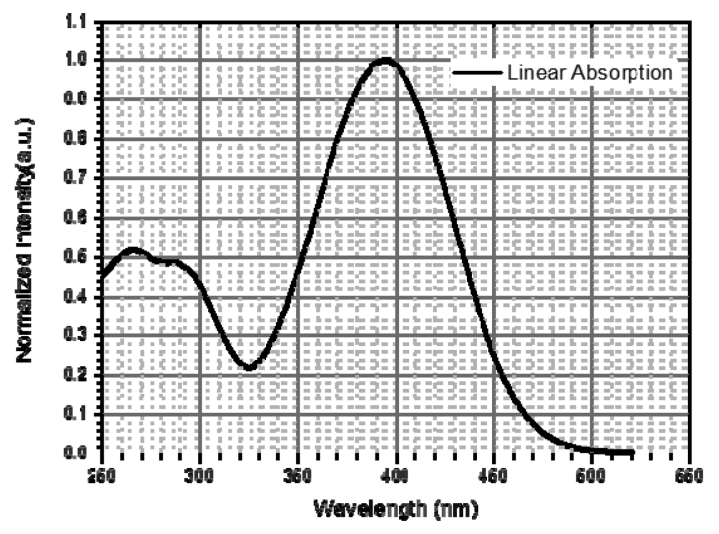<smiles>O=C(Nc1ccc2c(c1)CCC(c1ccc([N+](=O)[O-])cc1)=C2)Oc1ccccc1</smiles>

23

(b)

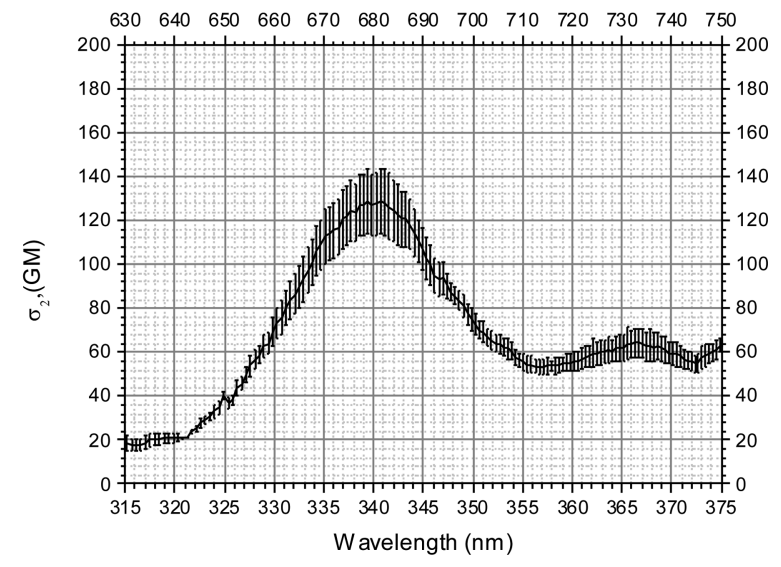

Figure 6. (a) OPA spectra of compound $23, \lambda 250-550 \mathrm{~nm}$. (b) TPA spectra of compound $23, \lambda$ $630-750 \mathrm{~nm}$. 
POST-PRINT: dx.doi.org/10.1021/jo501425p I J. Org. Chem. 2014, 79, 7822-7830

\section{SUMMARY}

In summary, this study designed and synthesized two new caged glutamates with $\pi$ extended 1,2-dihydronaphthalene chromophore. The synthetic sequence was highly convergent with an overall yield of approximately $28 \%$. These two caged glutamates 4 and 5 showed excellent buffer solubility (up to $115 \mathrm{mM}$ ), with the photochemical reaction shown to release glutamic acids in high yields (>95\%). A TPA value of $\sim 120 \mathrm{GM}$ at 680 $\mathrm{nm}$ was obtained for the parent structure 23. Further elaboration of this sequence for more efficient caged glutamates is currently underway in our laboratory.

\section{EXPERIMENTAL SECTION}

Commercially available reagents and solvents for syntheses were reagent grade and used without further purification. ${ }^{1} \mathrm{H}$ and ${ }^{13} \mathrm{C}$ NMR spectra were recorded with an NMR spectrometer. $\mathrm{CDCl}_{3}$ $(0.03 \% \mathrm{TMS})$ was used as deuterated solvents. Chemical shifts were reported in parts per million (ppm) relative to tetramethylsilane, and the coupling constants (J) was reported in Hertz (Hz). While the HRMS spectra was recorded on a Orbitrap XL instrument using the positive ion mode.

The synthetic procedures for new compounds prepared in this study follow.

6'-Bromo-3',4'-dihydro-1'H-spiro[[1,3]dioxolane-2,2'-naph- thalene] (11). 6-Bromo-3,4dihydronaphthalen-2(1H)-one (9) $(4.5 \mathrm{~g}, 20.1 \mathrm{mmol})$ was dissolved in benzene $(50 \mathrm{~mL})$, to which ethylene glycol $(2.27 \mathrm{~mL}, 40.2 \mathrm{mmol})$ and p-TSA $\cdot \mathrm{H}_{2} \mathrm{O}(191 \mathrm{mg}, 1.0 \mathrm{mmol})$ were added. The solution was heated under reflux conditions with a Dean-Stark trap attached for $6 \mathrm{~h}$. The reaction mixture was cooled and washed with saturated aq $\mathrm{NaHCO}_{3}(20 \mathrm{~mL})$ and water $(20 \mathrm{~mL})$. The organic layer was dried over $\mathrm{Na}_{2} \mathrm{SO}_{4}$, filtered, and evaporated under reduced pressure. Crude was purified by flash silica gel column chromatography (15\% ethyl acetate in hexanes) to give required compound 11 (5.2 g, 95\%): IR (neat) v 2951, 2881, 1591, 1484, 1104, 1062, 859, 803, $701 \mathrm{~cm}^{-1}$; ${ }^{1} \mathrm{H}$ NMR $\left(500 \mathrm{MHz}, \mathrm{CDCl}_{3}\right) \delta 7.27(\mathrm{~s}, 1 \mathrm{H}), 7.23(\mathrm{dd}, \mathrm{J}=8.5,2.1 \mathrm{~Hz}, 1 \mathrm{H}), 6.91(\mathrm{~d}, \mathrm{~J}=$ $8.2 \mathrm{~Hz}, 1 \mathrm{H}), 4.04-4.00(\mathrm{~m}, 4 \mathrm{H}), 2.95(\mathrm{t}, \mathrm{J}=6.9 \mathrm{~Hz}, 2 \mathrm{H}), 2.92(\mathrm{~s}, 2 \mathrm{H}), 1.93(\mathrm{t}, \mathrm{J}=6.8 \mathrm{~Hz}, 2 \mathrm{H})$; ${ }^{13} \mathrm{C}$ NMR $\left(125 \mathrm{MHz}, \mathrm{CDCl}_{3}\right) \delta$ 137.6, 133.4, 131.2, 130.7, 128.8, 119.6, 107.8, 64.5, 38.7, 31.4, 27.8; HRMS-APCI calcd for $\mathrm{C}_{12} \mathrm{H}_{14} \mathrm{O}_{2} \mathrm{Br} 269.0171$, found $269.0172[\mathrm{M}+\mathrm{H}]^{+}$.

tert-Butyl (3',4'-Dihydro-1'H-spiro[[1,3]dioxolane-2,2'-naph- thalen]-6'-yl)carbamate (12). 6'Bromo-3',4'-dihydro-1'H-spiro- [[1,3]dioxolane-2,2'-naphthalene] $(3.7 \mathrm{~g}, 13.7 \mathrm{mmol})$, tert-butyl carbamate $11(1.93 \mathrm{~g}, 16.5 \mathrm{mmol})$, cesium carbonate $(6.72 \mathrm{~g}, 20.6 \mathrm{mmol}), \mathrm{Pd}_{2}(\mathrm{dba})_{3}(125 \mathrm{mg}$, $0.13 \mathrm{mmol})$, and xanthphos $(238 \mathrm{mg}, 0.41 \mathrm{mmol})$ in anhydrous dioxane $(20 \mathrm{~mL})$ were heated at $100{ }^{\circ} \mathrm{C}$ under nitrogen atmosphere for $5 \mathrm{~h}$. The reaction mixture was cooled to room temperature, diluted with dichloromethane $(50 \mathrm{~mL})$, filtered, and concentrated in vacuo. The crude was purified by flash silica gel column chromatography (20\% ethyl acetate in hexanes) to give the required compound 12 (3.56 g, 85\%): $\mathrm{mp} 144-145^{\circ} \mathrm{C}$; IR (neat) v 3337, 2977, 1724, 1532, 1366, $1243,1058,882,814 \mathrm{~cm}^{-1} ;{ }^{1} \mathrm{H}$ NMR $\left(500 \mathrm{MHz}, \mathrm{CDCl}_{3}\right) \delta 7.20(\mathrm{~s}, 1 \mathrm{H}), 7.02(\mathrm{dd}, \mathrm{J}=7.8,2.1 \mathrm{~Hz}$, 
1H), $6.94(\mathrm{~d}, \mathrm{~J}=7.8 \mathrm{~Hz}, 1 \mathrm{H}), 6.46(\mathrm{~s}, 1 \mathrm{H}), 4.03-3.99(\mathrm{~m}, 4 \mathrm{H}), 2.94(\mathrm{t}, \mathrm{J}=6.9 \mathrm{~Hz}, 2 \mathrm{H}), 2.92(\mathrm{~s}$, $2 \mathrm{H}), 1.92(\mathrm{t}, \mathrm{J}=6.7 \mathrm{~Hz}, 2 \mathrm{H}), 1.50(\mathrm{~s}, 9 \mathrm{H}) ;{ }^{13} \mathrm{C} \mathrm{NMR}\left(125 \mathrm{MHz}, \mathrm{CDCl}_{3}\right) \delta 152.8,136.3,135.9$, $129.5,129.1,118.3,116.6,108.3,80.2,64.4,38.5,31.7,28.3,28.1$; HRMS-ESI calcd for $\mathrm{C}_{17} \mathrm{H}_{23} \mathrm{O}_{4} \mathrm{NNa} 328.1519$, found $328.1524[\mathrm{M}+\mathrm{Na}]^{+}$.

6-((tert-Butoxycarbonyl)amino)-3,4-dihydronaphthalen-2-yl Trifluoromethanesulfonate (7). To the stirred solution of tert-butyl $\left(3^{\prime}, 4^{\prime}\right.$-dihydro-1'H-spiro[[1,3]dioxolane-2,2'-naphthalen]-6'-yl)carbamate (12) (3 g, $9.83 \mathrm{mmol})$ in acetone $(30 \mathrm{~mL})$ was added p- TSA $\cdot \mathrm{H}_{2} \mathrm{O}(186 \mathrm{mg}, 0.97$ $\mathrm{mmol}$ ). Stirring was continued for $3 \mathrm{~h}$ at room temperature. After completion of reaction, the reaction mixture was cooled to $0{ }^{\circ} \mathrm{C}$ and quenched with saturated aqueous $\mathrm{NaHCO}_{3}(10 \mathrm{~mL})$. The reaction mixture was evaporated at reduced pressure, and the aqueous layer was extracted with ethyl acetate $(3 \times 20 \mathrm{~mL})$. The organic layers were combined, dried over $\mathrm{Na}_{2} \mathrm{SO}_{4}$, filtered, evaporated under reduced pressure, and purified through silica gel column chromatography $(20 \%$ ethyl acetate in hexanes) to give required compound 13 ( $2 \mathrm{~g}, 80 \%)$. The product was not stable, so it was used immediately in the next step.

tert-Butyl (6-oxo-5,6,7,8-tetrahydronaphthalen-2-yl)carbamate (13) (750 mg, $2.87 \mathrm{mmol}$ ) and Nphenylbis(trifluoromethanesulfonimide) $(1.33 \mathrm{~g}, 3.7 \mathrm{mmol})$ were dissolved in anhydrous THF (30 $\mathrm{mL}$ ), and the mixture was cooled to $-78{ }^{\circ} \mathrm{C}$ under nitrogen atmosphere. To this solution sodium bis(trimethylsilyl)amide (0.6 M solution in toluene, $9.5 \mathrm{~mL}, 5.74 \mathrm{mmol}$ ) was added dropwise via syringe at $-78{ }^{\circ} \mathrm{C}$ slowly dropwise (color changes to orange). The mixture was stirred at $-78{ }^{\circ} \mathrm{C}$ for an additional $30 \mathrm{~min}$ (monitored by TLC) before the reaction was quenched by addition of distilled water. The reaction mixture was then extracted with $\mathrm{Et}_{2} \mathrm{O}(3 \times 10 \mathrm{~mL})$, washed with brine $(20 \mathrm{~mL})$, dried over $\mathrm{Na}_{2} \mathrm{SO}_{4}$, and filtered, and the solvent was evaporated in vacuo. Purification by flash silica gel column chromatography (10\% ethyl acetate in hexanes) afforded required compound 7 (1.12 g, 75\%): $\mathrm{mp} 80-82{ }^{\circ} \mathrm{C}$; IR (neat) v 3318, 2995, 1693, 1580, 1522, 1240, 1141, 1061, 886, $755 \mathrm{~cm}^{-1} ;{ }^{1} \mathrm{H}$ NMR (500 MHz, $\left.\mathrm{CDCl}_{3}\right) \delta 7.32(\mathrm{~s}, 1 \mathrm{H}), 7.06$ (dd, J = 8.2, $2.2 \mathrm{~Hz}, 1 \mathrm{H}), 6.98(\mathrm{~d}, \mathrm{~J}=8.2 \mathrm{~Hz}, 1 \mathrm{H}), 6.50(\mathrm{~s}, 1 \mathrm{H}), 6.42(\mathrm{~s}, 1 \mathrm{H}), 3.02(\mathrm{t}, \mathrm{J}=8.5 \mathrm{~Hz}, 2 \mathrm{H}), 2.66(\mathrm{t}, \mathrm{J}$ $=8.5 \mathrm{~Hz}, 2 \mathrm{H}), 1.52(\mathrm{~s}, 9 \mathrm{H}) ;{ }^{13} \mathrm{C} \mathrm{NMR}\left(125 \mathrm{MHz} \mathrm{CDCl}_{3}\right) \delta 152.6,148.7,138.5,134.1,127.8$, $125.9,119.9,118.1,117.6,116.5,80.8,28.8,28.3,26.4$; HRMS- ESI calcd for $\mathrm{C}_{16} \mathrm{H}_{18} \mathrm{O}_{5} \mathrm{NF}_{3} \mathrm{NaS}$ 416.0750, found $416.0747[\mathrm{M}+\mathrm{Na}]^{+}$.

(5-Bromo-2-nitrophenyl)methanol (15). To a stirred solution of 5-bromo-2-nitrobenzaldehyde (14) $(1 \mathrm{~g}, 4.38 \mathrm{mmol})$ in methanol $(20 \mathrm{~mL})$ at $0{ }^{\circ} \mathrm{C}$ was added sodium borohydride $(162 \mathrm{mg}, 4.38$ $\mathrm{mmol}$ ) in portions. Stirring was continued for an additional $15 \mathrm{~min}$ at room temperature for complete reaction to take place. Methanol was evaporated from the reaction mixture, the reaction was quenched with cold water, and the mixture was extracted with ethyl acetate $(3 \times 20 \mathrm{~mL})$. Combined organic layers was washed with brine $(20 \mathrm{~mL})$, dried over $\mathrm{NaSO}_{4}$, and filtered. The solvent was evaporated under reduced pressure and purified through flash silica gel column chromatography (30\% ethyl acetate in hexanes) to give the required product $15(1.0 \mathrm{~g}$, quantitative): $\mathrm{mp} 91-92{ }^{\circ} \mathrm{C}$; IR (neat) v 3252, 1601, 1518, 1346, 1040, 831, $746 \mathrm{~cm}^{-1}$; ${ }^{1} \mathrm{H} \mathrm{NMR}$ (500 MHz, CD 3 OD) $\delta 7.97(\mathrm{~s}, 1 \mathrm{H}), 7.91(\mathrm{~d}, \mathrm{~J}=8.1 \mathrm{~Hz}, 1 \mathrm{H}), 7.56(\mathrm{dd}, \mathrm{J}=1.9,8.8 \mathrm{~Hz}, 1 \mathrm{H}), 4.90$

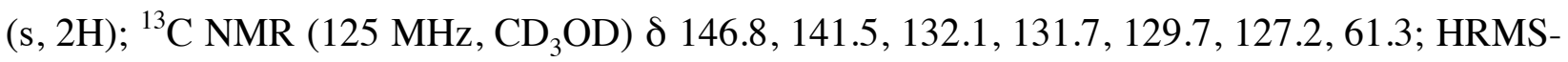
APCI calcd for $\mathrm{C}_{7} \mathrm{H}_{6} \mathrm{O}_{3} \mathrm{NBr} 230.9525$, found $230.9525[\mathrm{M}]^{+}$. 
((5-Bromo-2-nitrobenzyl)oxy)-tert-butyldimethylsilane (16). To a stirred solution of (5-bromo-2nitrophenyl)methanol (15) (1 g, $4.3 \mathrm{mmol})$ in $\mathrm{CH}_{2} \mathrm{Cl}_{2}(20 \mathrm{~mL})$ at $0{ }^{\circ} \mathrm{C}$ was added imidazole (586 $\mathrm{mg}, 8.62 \mathrm{mmol}$ ). After the solution was stirred for $10 \mathrm{~min}$, tert- butyldimethylsilyl chloride (969 $\mathrm{mg}, 6.46 \mathrm{mmol}$ ) was added. The temperature was raised to $25^{\circ} \mathrm{C}$, and stirring was continued for an additional $12 \mathrm{~h}$ at room temperature. After completion of reaction, water $(20 \mathrm{~mL})$ was added to reaction mixture. The organic layer was separated, washed with brine $(20 \mathrm{~mL})$, dried over $\mathrm{Na}_{2} \mathrm{SO}_{4}$, and filtered. Solvent was evaporated under reduced pressure and purified through flash silica gel column chromatography (5\% ethyl acetate in hexanes) to give the required product 16 (1.35 g, 90\%): $\mathrm{mp} 38-40{ }^{\circ} \mathrm{C}$; IR (neat) v 2955, 2857, 1604, 1566, 1343, 1109, 837, $779 \mathrm{~cm}^{-1} ;{ }^{1} \mathrm{H}$ NMR (500 MHz, CDCl $\left.{ }_{3}\right) \delta 8.08(\mathrm{~s}, 1 \mathrm{H}), 7.99(\mathrm{~d}, \mathrm{~J}=8.6 \mathrm{~Hz}, 1 \mathrm{H}), 7.55(\mathrm{~d}, \mathrm{~J}=8.8 \mathrm{~Hz}, 1 \mathrm{H}), 5.08$ (s, 2H), 0.98 (s, 9H), $\left.0.16(\mathrm{~s}, 6 \mathrm{H}) ;{ }^{13} \mathrm{C} \mathrm{NMR} \mathrm{(125} \mathrm{MHz,} \mathrm{CDCl}_{3}\right) \delta$ 145.1, 140.5, 131.3, 130.6, 129.4, 126.1, 61.8, 25.9, 18.3, -5.4; HRMS-APCI calcd for $\mathrm{C}_{13} \mathrm{H}_{21} \mathrm{O}_{3} \mathrm{NBrSi} 346.0468$, found $346.0472[\mathrm{M}+\mathrm{H}]^{+}$.

tert-Butyl((5-(5,5-dimethyl-1,3,2-dioxaborinan-2-yl)-2-nitro- benzyl)-oxy)dimethylsilane (8). A mixture of ((5-bromo-2- nitrobenzyl)oxy)(tert-butyl)dimethylsilane 16 (1.2 g, $3.47 \mathrm{mmol})$, potassium acetate $(1.02 \mathrm{~g}, 10.4 \mathrm{mmol}), \mathrm{Pd}(\mathrm{dppf}) \mathrm{Cl}_{2}(142 \mathrm{mg}, 0.17 \mathrm{mmol})$ and bis(neopentyl glycolate)diboron $(1.18 \mathrm{~g}, 5.2 \mathrm{mmol})$ in acetonitrile $(20 \mathrm{~mL})$ was heated at reflux under nitrogen atmosphere for $1 \mathrm{~h}$. The reaction mixture was cooled to room temperature, diluted with ethyl acetate $(50 \mathrm{~mL})$ and filtered with Celite. The filtrate was concentrated under reduced pressure and purified through silica gel column chromatography (10\% ethyl acetate in hexanes) to afford required compound 8 (1.18 g, 90\%). m.p: $40-41{ }^{\circ} \mathrm{C}$; IR (neat) v 2958, 2857, 1520, 1479, 1335 , 1255, 1130, 838, $778 \mathrm{~cm}^{-1}$; ${ }^{1} \mathrm{H}$ NMR $\left(500 \mathrm{MHz}, \mathrm{CDCl}_{3}\right) \delta 8.28(\mathrm{~s}, 1 \mathrm{H}), 7.99(\mathrm{~d}, \mathrm{~J}=8.0 \mathrm{~Hz}, 1 \mathrm{H})$, $7.80(\mathrm{~d}, \mathrm{~J}=8.1 \mathrm{~Hz}, 1 \mathrm{H}), 5.08(\mathrm{~s}, 2 \mathrm{H}), 3.79(\mathrm{~s}, 4 \mathrm{H}), 1.03(\mathrm{~s}, 6 \mathrm{H}), 0.97(\mathrm{~s}, 9 \mathrm{H}), 0.13(\mathrm{~s}, 6 \mathrm{H}) ;{ }^{13} \mathrm{C}$ NMR $\left(125 \mathrm{MHz}, \mathrm{CDCl}_{3}\right) \delta 148.3,136.3,133.9,132.9,123.3,62.3,31.9,25.9,21.8,18.4,-5.4$; HRMS-APCI calcd for $\mathrm{C}_{18} \mathrm{H}_{31} \mathrm{O}_{5} \mathrm{NBSi}$ : 380.2059 , found $380.2065[\mathrm{M}+\mathrm{H}]^{+}$.

tert-Butyl (6-(3-(((tert-Butyldimethylsilyl)oxy)methyl)-4-ni- trophenyl)-7,8-dihydronaphthalen2-yl)carbamate (17). A mag- netically stirred solution of 6-((tert-butoxycarbonyl)amino)-3,4dihy- dronaphthalen-2-yl trifluoro-methanesulfonate (7) $(1 \mathrm{~g}, 2.54 \mathrm{mmol})$ in $\mathrm{THF} / \mathrm{H}_{2} \mathrm{O}(60 \mathrm{~mL})$ (9:1) was mixed with tert-butyl((5-(5,5-dimethyl- 1,3,2-dioxaborinan-2-yl)-2-nitrobenzyl)oxy)dimethylsilane $(1 \mathrm{~g}, 2.63 \mathrm{mmol})$, triethylamine $(3.5 \mathrm{~mL}, 25.3 \mathrm{mmol})$, and $\mathrm{Pd}(\mathrm{dppf}) \mathrm{Cl}_{2}(207$ $\mathrm{mg}, 0.25 \mathrm{mmol})$. The reaction was run under nitrogen atmosphere with refluxing for $1 \mathrm{~h}$. The cooled reaction mixture was diluted with ethyl acetate $(100 \mathrm{~mL})$, washed with water $(50 \mathrm{~mL})$ and brine $(50 \mathrm{~mL})$, dried over $\mathrm{Na}_{2} \mathrm{SO}_{4}$, and filtered, and solvent was evaporated under reduced pressure and purified through silica gel column chromatography (10\% ethyl acetate in hexanes)

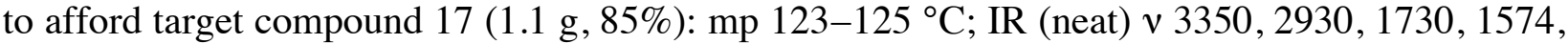
1516, 1332, 1252, 1106, 836, $\left.778 \mathrm{~cm}^{-1} ;{ }^{1} \mathrm{H} \mathrm{NMR} \mathrm{(500} \mathrm{MHz,} \mathrm{CDCl}_{3}\right) \delta 8.14(\mathrm{~d}, \mathrm{~J}=8.7 \mathrm{~Hz}, 1 \mathrm{H})$, 8.09-8.06 (m, 1H), 7.52 (dd, J = 8.4, 2.0 Hz, 1H), 7.35 (s, 1H), 7.12-7.06 (m, 2H), 6.99 (s, 1H), $6.53(\mathrm{~s}, 1 \mathrm{H}), 5.15(\mathrm{~s}, 2 \mathrm{H}), 2.96(\mathrm{t}, \mathrm{J}=8.5 \mathrm{~Hz}, 2 \mathrm{H}), 2.75(\mathrm{t}, \mathrm{J}=8.5 \mathrm{~Hz}, 2 \mathrm{H}), 1.53(\mathrm{~s}, 9 \mathrm{H}), 1.00(\mathrm{~s}$, 9H), $0.16(\mathrm{~s}, 6 \mathrm{H}) ;{ }^{13} \mathrm{C}$ NMR $\left(125 \mathrm{MHz}, \mathrm{CDCl}_{3}\right) \delta$ 152.6, 146.8, 144.4, 138.9, 138.1, 136.4, 135.0, 129.2, 127.9, 127.4, 125.2, 123.8, 123.3, 117.4, 116.4, 80.7, 62.3, 28.3, 28.2, 25.9, 25.8, 18.3, -5.4; HRMS-ESI calcd for $\mathrm{C}_{28} \mathrm{H}_{38} \mathrm{O}_{5} \mathrm{~N}_{2} \mathrm{NaSi}$ 533.2442, found 533.2438 [M + Na] ${ }^{+}$. 
(5-(6-Amino-3,4-dihydronaphthalen-2-yl)-2-nitrophenyl)- methanol (6). To a stirred solution of tert-butyl (6-(3-(((tert- butyldimethylsilyl)oxy)methyl)-4-nitrophenyl)-7,8-dihydronaphtha- len-2yl)carbamate (17) $(1 \mathrm{~g}, 1.96 \mathrm{mmol})$ in THF $(40 \mathrm{~mL})$ was added slowly TFA $(10 \mathrm{~mL})$ at $0{ }^{\circ} \mathrm{C}$. Subsequently, the temperature was raised to $25^{\circ} \mathrm{C}$ and stirring was continued for an additional 1 $\mathrm{h}$. After completion of the reaction, the reaction mixture was evaporated, quenched with saturated aqueous $\mathrm{NaHCO}_{3}(10 \mathrm{~mL})$, and extracted with ethyl acetate $(3 \times 20 \mathrm{~mL})$, the combined organic layers were dried over $\mathrm{Na}_{2} \mathrm{SO}_{4}$ and filtered, and solvent was evaporated under reduced pressure and purified through silica gel column chromatog- raphy (5\% methanol in chloroform) to afford target compound 6 (550 mg, 95\%): $\mathrm{mp} 138-140{ }^{\circ} \mathrm{C}$; IR (KBr): v 3389, 3276, 2931, 1599, 1497 , 1214, 1082, 878, 832, $755 \quad \mathrm{~cm}^{-1} ; \quad{ }^{1} \mathrm{H} \quad \mathrm{NMR} \quad(500 \quad \mathrm{MHz}, \quad$ DMSO$\left.\mathrm{d}_{6}\right) \delta 8.05(\mathrm{~d}, \mathrm{~J}=8.7 \mathrm{~Hz}, 1 \mathrm{H}), 7.95(\mathrm{~s}, 1 \mathrm{H}), 7.61(\mathrm{~d}, \mathrm{~J}=8.2 \mathrm{~Hz}, 1 \mathrm{H}), 7.08(\mathrm{~s}, 1 \mathrm{H}), 6.95(\mathrm{~d}, \mathrm{~J}=8.1 \mathrm{~Hz}, 1 \mathrm{H})$, $6.99(\mathrm{~s}, 1 \mathrm{H}), 6.44-6.38(\mathrm{~m}, 2 \mathrm{H}), 5.56(\mathrm{t}, \mathrm{J}=5.6 \mathrm{~Hz}, 1 \mathrm{H}), 5.38(\mathrm{~s}, 2 \mathrm{H}), 4.88(\mathrm{~d}, \mathrm{~J}=5.5 \mathrm{~Hz}, 2 \mathrm{H})$, $2.77(\mathrm{t}, \mathrm{J}=8.4 \mathrm{~Hz}, 2 \mathrm{H}), 2.63(\mathrm{t}, \mathrm{J}=8.4 \mathrm{~Hz}, 2 \mathrm{H}),{ }^{13} \mathrm{CNMR}\left(125 \mathrm{MHz}, \mathrm{DMSO}-\mathrm{d}_{6}\right) \delta 149.3,146.4,143.9$, 139.2, 136.4, 129.6, 128.9, 128.4, 128.3, 123.2, 122.9, 122.3, 112.8, 111.6, 60.3, 28.0, 25.1; HRMS- ESI calcd for $\mathrm{C}_{17} \mathrm{H}_{16} \mathrm{O}_{3} \mathrm{~N}_{2} \mathrm{Na} 319.1053$, found $319.1057[\mathrm{M}+\mathrm{Na}]^{+}$.

(5-(6-(Bis(2-(2-(2-methoxyethoxy)ethoxy)ethyl)amino)-3,4-

dihydronaphthalen-2-yl)-2nitrophenyl)methanol (18). To an anhydrous acetonitrile $(8.0 \mathrm{~mL})$ solution of $(5-(6$-amino-3,4dihydronaphthalen-2-yl)-2-nitrophenyl)methanol (6) (204 mg, $0.68 \mathrm{mmol}$ ), sodium iodide (1 g, $6.6 \mathrm{mmol})$, and N-ethyldiisopropylamine $(436 \mathrm{mg}, 3.37 \mathrm{mmol})$ was added 1-bromo-2-(2-(2methoxyethoxy)- ethoxy)ethane $(760 \mathrm{mg}, 3.34 \mathrm{mmol})$. The reaction mixture was heated under reflux for 5 days. After the mixture was cooled to room temperature, white solids were filtered. The filtrate was washed with water, dried over $\mathrm{Na}_{2} \mathrm{SO}_{4}$, and purified through silica gel column chromatography (100\% ethyl acetate) to afford required compound 18 (303 $\mathrm{mg}, 75 \%)$ : IR (neat) $v$ 3435, 2821, 1595, 1511, 1328, 1213, 1086, 1030, 835, $799 \mathrm{~cm}^{-1} ;{ }^{1} \mathrm{H}$ NMR $\left(500 \mathrm{MHz}, \mathrm{CD}_{3} \mathrm{CN}\right)$ $\delta 8.13(\mathrm{~d}, \mathrm{~J}=8.7 \mathrm{~Hz}, 1 \mathrm{H}), 7.79(\mathrm{~d}, \mathrm{~J}=1.9 \mathrm{~Hz}, 1 \mathrm{H}), 7.54(\mathrm{dd}, \mathrm{J}=8.8,2.1 \mathrm{~Hz}, 1 \mathrm{H}), 7.04(\mathrm{~d}, \mathrm{~J}=9.0$ $\mathrm{Hz}, 1 \mathrm{H}), 6.57-6.53(\mathrm{~m}, 2 \mathrm{H}), 5.00(\mathrm{~d}, \mathrm{~J}=3.3,2 \mathrm{H}), 3.69-3.59(\mathrm{~m}, 20 \mathrm{H}), 3.57-3.53(\mathrm{~m}, 4 \mathrm{H}), 3.38$ $(\mathrm{s}, 6 \mathrm{H}), 2.92(\mathrm{t}, \mathrm{J}=8.5 \mathrm{~Hz}, 2 \mathrm{H}), 2.73(\mathrm{t}, \mathrm{J}=8.5 \mathrm{~Hz}, 2 \mathrm{H}) ;{ }^{13} \mathrm{C} \mathrm{NMR}\left(125 \mathrm{MHz}, \mathrm{CD}_{3} \mathrm{CN}\right) \delta 149.2$, $148.0,145.5,139.7,138.0,129.9,129.0,126.2$, 124.6, 124.0, 118.3, 111.8, 110.6, 72.6, 71.4, 71.2, 71.1, 69.3, 62.2, 58.9, 51.6, 29.5, 26.5; HRMS-ESI calcd for $\mathrm{C}_{31} \mathrm{H}_{44} \mathrm{O}_{9} \mathrm{~N}_{2} \mathrm{Na} 611.2939$, found $611.2934[\mathrm{M}+\mathrm{Na}]^{+}$.

(S)-5-(5-(6-(Bis(2-(2-(2-Methoxyethoxy)ethoxy)ethyl)amino)- 3,4-dihydronaphthalen-2-yl)-2nitrobenzyl) 1-tert-Butyl 2- ((tert-butoxycarbonyl)amino)pentanedioate (20). To a solution of (5(6-(bis(2-(2-(2-methoxyethoxy)ethoxy)ethyl)amino)-3,4-dihydronaphthalen-2-yl)-2nitrophenyl)methanol (18) (110 mg, $0.18 \mathrm{mmol})$ in DCM (2 mL) were added (S)-5-tert-butoxy-4((tert- butoxycarbonyl)amino)-5-oxopentanoic acid (113 mg, $0.37 \mathrm{mmol})$, EDC (53.8 $\mathrm{mg}, 0.28$ $\mathrm{mmol}$ ), and DMAP (2.2 $\mathrm{mg}, 0.018 \mathrm{mmol})$. The reaction was allowed to stir for $20 \mathrm{~h}$ for complete reaction. The reaction was diluted with $\mathrm{CH}_{2} \mathrm{Cl}_{2}(5 \mathrm{~mL})$, washed with $1 \mathrm{M} \mathrm{HCl}$, saturated $\mathrm{NaHCO}_{3}$ solution, and brine, dried over $\mathrm{Na}_{2} \mathrm{SO}_{4}$, and concentrated in vacuo. The residue was purified by silica gel column chromatography (100\% ethyl acetate) to provide required compound 20 (147 $\mathrm{mg}, 90 \%)$ : IR (neat) v 3336, 2876, 1738, 1598, 1472, 1393, 1213, 1149, 932, 847, $798 \mathrm{~cm}^{-1} ;{ }^{1} \mathrm{H}$ NMR $\left(500 \mathrm{MHz}, \mathrm{CD}_{3} \mathrm{CN}\right) \delta 8.08(\mathrm{dd}, \mathrm{J}=8.8,2.4 \mathrm{~Hz}, 1 \mathrm{H}), 7.73(\mathrm{~s}, 1 \mathrm{H}), 7.62(\mathrm{~d}, \mathrm{~J}=9.1 \mathrm{~Hz}, 1 \mathrm{H})$, $7.07(\mathrm{~s}, 1 \mathrm{H}), 7.04(\mathrm{~d}, \mathrm{~J}=8.3 \mathrm{~Hz}, 1 \mathrm{H}), 6.59(\mathrm{~s}, 1 \mathrm{H}), 6.55(\mathrm{~d}, \mathrm{~J}=8.5 \mathrm{~Hz}, 1 \mathrm{H}), 5.55$ (d, J = $7.8 \mathrm{~Hz}$, 
$1 \mathrm{H}), 5.47(\mathrm{~s}, 2 \mathrm{H}), 4.07-3.98(\mathrm{~m}, 1 \mathrm{H}), 3.63-3.52(\mathrm{~m}, 20 \mathrm{H}), 3.45(\mathrm{t}, \mathrm{J}=4.2,4 \mathrm{H}), 3.28(\mathrm{~s}, 6 \mathrm{H})$, $2.87(\mathrm{t}, \mathrm{J}=8.2,2 \mathrm{H}), 2.68(\mathrm{t}, \mathrm{J}=8.2,2 \mathrm{H}), 2.50(\mathrm{t}, \mathrm{J}=7.5 \mathrm{~Hz}, 2 \mathrm{H}), 2.14-2.04(\mathrm{~m}, 1 \mathrm{H}), 1.93-1.85$ $(\mathrm{m}, 1 \mathrm{H}), 1.42(\mathrm{~s}, 9 \mathrm{H}), 1.38(\mathrm{~s}, 9 \mathrm{H}) ;{ }^{13} \mathrm{C} \mathrm{NMR}\left(125 \mathrm{MHz}, \mathrm{CD}_{3} \mathrm{CN}\right) \delta 173.2,149.4,148.2,145.9$, $138.0,133.5,131.3,130.0,129.6,129.5,126.6,125.4,125.1,123.5,118.3,111.8,110.6,82.3$, 79.9, 72.6, 73.4, 71.2, 71.1, 69.3, 64.2, 58.9, 51.6, 31.1, 29.5, 28.5, 28.1 , 27.8, 26.4; HRMS-ESI calcd for $\mathrm{C}_{45} \mathrm{H}_{67} \mathrm{O}_{14} \mathrm{~N}_{3} \mathrm{Na} 896.4515$, found $896.4490[\mathrm{M}+\mathrm{Na}]^{+}$.

(S)-2-Amino-5-((5-(6-(bis(2-(2-(2-methoxyethoxy)ethoxy)- ethyl)amino)-3,4-dihydronaphthalen2-yl)-2-nitrobenzyl)oxy)- 5-oxopentanoic Acid (4). To a stirred solution of (S)-5-(5-(6- (bis(2-(2(2-ethoxyethoxy)ethoxy)ethyl)amino)-3,4-dihydronaphtha- len-2-yl)-2-nitrobenzyl) 1-tert-butyl 2-((tert-butoxycarbonyl)amino)- pentanedioate $20(25 \mathrm{mg}, 0.028 \mathrm{mmol})$ in anhydrous $\mathrm{CH}_{2} \mathrm{Cl}_{2}(1$ $\mathrm{mL})$ was added trifluoroacetic acid $(0.25 \mathrm{~mL})$. After $5 \mathrm{~h}$ at room temperature under nitrogen atmosphere the solution was evaporated to yield caged glutamate 4 (20 mg, quantitative yield): IR (neat) v3445, 2891, 2608, 196, 1784, 1696, 1514, 1333, 1131, 764, $594 \mathrm{~cm}^{-1} ;{ }^{1} \mathrm{H}$ NMR $(500$ MHz, DMSO-d) $\delta 8.32$ (s, 3H), $8.11(\mathrm{~d}, \mathrm{~J}=8.2 \mathrm{~Hz}, 1 \mathrm{H}), 7.77(\mathrm{~s}, 1 \mathrm{H}), 7.74$ (dd, J = 8.8, $1.9 \mathrm{~Hz}$, $1 \mathrm{H}), 7.17(\mathrm{~s}, 1 \mathrm{H}), 7.08(\mathrm{~d}, \mathrm{~J}=8.5 \mathrm{~Hz}, 1 \mathrm{H}), 6.59(\mathrm{~s}, 1 \mathrm{H}), 6.54(\mathrm{dd}, \mathrm{J}=8.4,2.1 \mathrm{~Hz}, 1 \mathrm{H}), 5.47(\mathrm{~s}$, $2 \mathrm{H}), 3.98(\mathrm{~s}, 1 \mathrm{H}), 3.60-3.46(\mathrm{~m}, 20 \mathrm{H}), 3.41(\mathrm{t}, \mathrm{J}=4.1,4 \mathrm{H}), 3.23(\mathrm{~s}, 6 \mathrm{H}), 2.85(\mathrm{t}, \mathrm{J}=8.2,2 \mathrm{H})$, $2.66(\mathrm{t}, \mathrm{J}=8.2,2 \mathrm{H}), 2.71-2.53(\mathrm{~m}, 2 \mathrm{H}), 2.18-2.00(\mathrm{~m}, 2 \mathrm{H}) ;{ }^{13} \mathrm{C}$ NMR (125 MHz, DMSO-d) $\delta$ 171.33 , 147.93, 146.43, 144.67, 136.57, 131.68, 129.53, 128.96, 128.50, 125.59, 125.15, 124.41, 122.03, 110.47, 109.36, 71.24, 69.93, 69.80, 69.61, 67.90, 63.21, 57.99, 50.21, 29.14, 28.18, 27.40, 25.17, 24.94; HRMS- ESI calcd for $\mathrm{C}_{36} \mathrm{H}_{52} \mathrm{O}_{12} \mathrm{~N}_{3} 718.3546$, found 718.3545 [M + H] $]^{+}$.

tert-Butyl 2,2'-(6-(3-(Hydroxymethyl)-4-nitrophenyl)-7,8-di- $\quad$ hydronaphthalen-2ylazanediyl)diacetate (19). To an anhydrous acetonitrile $(2.0 \mathrm{~mL})$ solution of (5-(6-amino-3,4dihydronaphthalen- 2-yl)-2-nitrophenyl)methanol (6 )(25 mg, $0.084 \mathrm{mmol})$, sodium iodide (126.5 $\mathrm{mg}, 0.84 \mathrm{mmol}$ ), and N-ethyldiisopropylamine (54.6 $\mathrm{mg}, 0.42 \mathrm{mmol}$ ) was added tert-butyl bromoacetate $(164 \mathrm{mg}, 0.84 \mathrm{mmol})$. The reaction mixture was heated under reflux for $24 \mathrm{~h}$. After the mixture was cooled to room temperature, solvent was evaporated and diluted with $\mathrm{CH}_{2} \mathrm{Cl}_{2}$, and white solids were filtered. Filtrate was concentrated in vacuo and purified through silica gel column chromatography (20\% ethyl acetate in hexanes) to afford required compound 19 (35 $\mathrm{mg}$, $80 \%$ ): IR (neat) v 2978, 1734, 1597, 1510, 1456, 1330, 1213, 1149, 1085, 842, $622 \mathrm{~cm}^{-1} ;{ }^{1} \mathrm{H}$ NMR (400 MHz, $\left.\mathrm{CDCl}_{3}\right) \delta 8.10(\mathrm{dd}, \mathrm{J}=8.8,2.5 \mathrm{~Hz}, 1 \mathrm{H}), 7.75(\mathrm{~d}, \mathrm{~J}=1.9 \mathrm{~Hz}, 1 \mathrm{H}), 7.51(\mathrm{td}, \mathrm{J}=$ 8.5, $2.4 \mathrm{~Hz}, 1 \mathrm{H}), 7.01(\mathrm{~d}, \mathrm{~J}=7.2 \mathrm{~Hz}, 1 \mathrm{H}), 6.97(\mathrm{~s}, 1 \mathrm{H}), 6.42-6.40(\mathrm{~m}, 1 \mathrm{H}), 6.39$ (s, 1H), 4.97 (s, 2H), $4.01(\mathrm{~s}, 4 \mathrm{H}), 2.89(\mathrm{t}, \mathrm{J}=8.0 \mathrm{~Hz}, 2 \mathrm{H}), 2.64(\mathrm{t}, \mathrm{J}=8.0 \mathrm{~Hz}, 2 \mathrm{H}), 1.47(\mathrm{~s}, 18 \mathrm{H}) ;{ }^{13} \mathrm{C} \mathrm{NMR}(100$ $\left.\mathrm{MHz}, \mathrm{CDCl}_{3}\right) \delta 169.9,148.2,147.6,145.0,137.3,136.7,13.7,128.7,128.4,125.7,125.5,124.5$, $123.9,111.5,110.2,81.9,63.8,54.5,28.8,28.1,25.8$; HRMS-ESI calcd for $\mathrm{C}_{29} \mathrm{H}_{36} \mathrm{O}_{7} \mathrm{~N}_{2} \mathrm{Na}$ 547.2414 , found $547.2409[\mathrm{M}+\mathrm{Na}]^{+}$.

(S)-5-(5-(6-(Bis(2-tert-butoxy-2-oxoethyl)amino)-3,4-dihy- dronaphthalen-2-yl)-2-nitrobenzyl) 1-tert-Butyl 2-(tert- Butoxycarbonylamino)pentanedioate (21). To a solution of tert-butyl 2,2'-(6(3-(hydroxymethyl)-4-nitrophenyl)-7,8-dihydronaph- thalen-2-ylazanediyl)diacetate (19) (34 mg, $0.064 \mathrm{mmol})$ in DCM (2 mL) was added (S)-5-tert-butoxy-4-((tert-butoxycarbonyl)amino)-5oxopentanoic acid (22) (39 mg, $0.129 \mathrm{mmol})$, EDC (18.6 mg, $0.097 \mathrm{mmol})$, and DMAP (0.8 $\mathrm{mg}$, $0.0064 \mathrm{mmol})$. The reaction was allowed to stir for $12 \mathrm{~h}$ for complete reaction. The reaction was diluted with $\mathrm{CH}_{2} \mathrm{Cl}_{2}(5 \mathrm{~mL})$, washed with $1 \mathrm{M} \mathrm{HCl}$, saturated $\mathrm{NaHCO}_{3}$ solution, and brine, dried 
over $\mathrm{Na}_{2} \mathrm{SO}_{4}$, and concentrated in vacuo. The residue was purified by silica gel column chromatography (20\% ethyl acetate in hexanes) to provide required compound 21 (42 $\mathrm{mg}, 80 \%$ ): IR (neat) v 2979, 2930, 1741, 1600, 1577, 1506, 1457, 1333, 1216, 1152, 843, $797 \mathrm{~cm}^{-1} ;{ }^{1} \mathrm{H}$ NMR $\left(400 \mathrm{MHz}, \mathrm{CDCl}_{3}\right) \delta 8.11(\mathrm{dd}, \mathrm{J}=8.5 \mathrm{~Hz}, 1 \mathrm{H}), 7.63(\mathrm{~d}, \mathrm{~J}=2.0 \mathrm{~Hz}, 1 \mathrm{H}), 7.55(\mathrm{dd}, \mathrm{J}=8.6$, $2.0 \mathrm{~Hz}, 1 \mathrm{H}), 7.05(\mathrm{~d}, \mathrm{~J}=9.1 \mathrm{~Hz}, 1 \mathrm{H}), 6.95(\mathrm{~s}, 1 \mathrm{H}), 6.43-6.41(\mathrm{~m}, 1 \mathrm{H}), 6.40(\mathrm{~s}, 1 \mathrm{H}), 5.54(\mathrm{~s}, 1 \mathrm{H})$, $5.09(\mathrm{~d}, \mathrm{~J}=7.6 \mathrm{~Hz}, 1 \mathrm{H}), 4.27-4.17(\mathrm{~m}, 1 \mathrm{H}), 4.03(\mathrm{~s}, 4 \mathrm{H}), 2.90(\mathrm{t}, \mathrm{J}=7.7,2 \mathrm{H}), 2.70(\mathrm{t}, \mathrm{J}=7.7 \mathrm{~Hz}$, $6 \mathrm{H}), 2.60-2.41(\mathrm{~m}, 2 \mathrm{H}), 2.27-2.15(\mathrm{~m}, 1 \mathrm{H}), 2.01-1.90(\mathrm{~m}, 1 \mathrm{H}), 1.47(\mathrm{~s}, 18 \mathrm{H}), 1.45(\mathrm{~s}, 9 \mathrm{H}), 1.42$ (s, 9H); ${ }^{13} \mathrm{C}$ NMR $\left(100 \mathrm{MHz}, \mathrm{CDCl}_{3}\right) \delta 172.2,171.2,169.9,155.4,148.2,147.3,145.0,136.6$, 132.2, 131.5, 128.8, 128.4, 125.7, 124.9, 124.4, 124.3, 111.4, 110.2, 82.3, 81.8, 63.6, 54.5, 53.3, $30.2,28.8,28.3,28.1,27.9,25.8$; HRMS-ESI calcd for $\mathrm{C}_{43} \mathrm{H}_{59} \mathrm{O}_{12} \mathrm{~N}_{3} \mathrm{Na} 832.3991$, found $832.3994[\mathrm{M}+\mathrm{Na}]^{+}$.

(S)-2,2'-(6-(3-((4-Amino-4-carboxybutanoyloxy)methyl)-4- nitrophenyl)-7,8-dihydronaphthalen2-ylazanediyl)diacetic Acid (5). To a stirred solution of (S)-5-(5-(6-(bis(2-tert-butoxy-2oxoethyl)amino)-3,4-dihydronaphthalen-2-yl)-2-nitrobenzyl) 1-tert- butyl 2-(tertbutoxycarbonylamino)pentanedioate (21) $(40 \mathrm{mg}, 0.049 \mathrm{mmol})$ in anhydrous $\mathrm{CH}_{2} \mathrm{Cl}_{2}(3 \mathrm{~mL})$ was added trifluoroacetic acid $(1.0 \mathrm{~mL})$. After $5 \mathrm{~h}$ at room temperature under nitrogen atmosphere, the solution was evaporated to yield caged glutamate 5 (32 mg, quantitative yield): IR (neat) $v 3437$, 2935, 2633, 1734, 1601, 1510, 1331, 1190, 1139, 1080, $842 \mathrm{~cm}^{-1}$; ${ }^{1} \mathrm{H}$ NMR (400 MHz, DMSOd) $\delta 8.24(\mathrm{~s}, 3 \mathrm{H}), 8.05(\mathrm{~d}, \mathrm{~J}=8.1 \mathrm{~Hz}, 1 \mathrm{H}), 7.70(\mathrm{~d}, \mathrm{~J}=13.0 \mathrm{~Hz}, 1 \mathrm{H}), 7.12(\mathrm{~s}, 1 \mathrm{H}), 7.04(\mathrm{~d}, \mathrm{~J}=8.1$ $\mathrm{Hz}, 1 \mathrm{H}), 6.36(\mathrm{~s}, 1 \mathrm{H}), 6.31(\mathrm{~d}, \mathrm{~J}=7.7 \mathrm{~Hz}, 1 \mathrm{H}), 5.40(\mathrm{~s}, 2 \mathrm{H}), 4.07(\mathrm{~s}, 4 \mathrm{H}), 3.95-3.86(\mathrm{~m}, 1 \mathrm{H})$, $2.78(\mathrm{t}, \mathrm{J}=7.7 \mathrm{~Hz}, 2 \mathrm{H}), 2.60(\mathrm{t}, \mathrm{J}=7.7,2 \mathrm{H}), 2.56-2.46(\mathrm{~m}, 2 \mathrm{H}), 2.11-1.89(\mathrm{~m}, 2 \mathrm{H}) ;{ }^{13} \mathrm{C} \mathrm{NMR}$ (100 MHz, DMSO-d) $\delta 172.5,171.8,171.0,148.6,146.7,145.3,136.8,132.2,130.9,129.2$, 128.7, 126.1, 125.7, 125.0, 123.7, 111.1, 110.0, 63.6, 56.4, 53.3, 29.6, 28.5, 25.6, 25.4; HRMSESI calcd for $\mathrm{C}_{26} \mathrm{H}_{28} \mathrm{O}_{10} \mathrm{~N}_{3} 542.1769$, found $542.1765[\mathrm{M}+\mathrm{H}]^{+}$.

tert-Butyl (6-(4-Nitrophenyl)-7,8-dihydronaphthalen-2-yl)- carbamate (23). 6-((tertButoxycarbonyl)amino)-3,4-dihydronaph- thalen-2-yl trifluoromethanesulfonate 7 (200 mg, 0.5 $\mathrm{mmol}$ ), 4- nitrobenzeneboronic acid (170 mg, $1.0 \mathrm{mmol})$, cesium carbonate ( $829 \mathrm{mg}, 2.5 \mathrm{mmol})$, and $\mathrm{Pd}\left(\mathrm{PPh}_{3}\right)_{4}(58.8 \mathrm{mg}, 0.05 \mathrm{mmol})$ were mixed in 1,4-dioxane $(10 \mathrm{~mL})$ and $\mathrm{H}_{2} \mathrm{O}(2.0 \mathrm{~mL})$ in a round-bottom flask. The mixture was heated at $100{ }^{\circ} \mathrm{C}$ for $12 \mathrm{~h}$ and then partitioned between $\mathrm{H}_{2} \mathrm{O}$ and EtOAc. The insoluble solid was filtered, and the organic layer was concentrated in vacuo and purified through column chromatog- raphy to afford the desired product $23(170 \mathrm{mg}, 91 \%)$ : $\mathrm{mp}$ 153-155 ${ }^{\circ} \mathrm{C}$; IR (neat) v 3361, 2979, 1724, 1514, 1233, 1157, 852, $750 \mathrm{~cm}^{-1}$;

${ }^{1} \mathrm{HNMR}\left(500 \mathrm{MHz}, \mathrm{CDCl}_{3}\right) \delta 8.20(\mathrm{~d}, \mathrm{~J}=8.8 \mathrm{~Hz}, 2 \mathrm{H}), 7.63(\mathrm{~d}, \mathrm{~J}=8.9 \mathrm{~Hz}, 2 \mathrm{H}), 7.35(\mathrm{~s}, 1 \mathrm{H}), 7.10(\mathrm{~s}, 1 \mathrm{H})$, $6.96(\mathrm{~s}, 1 \mathrm{H}), 6.54(\mathrm{~s}, 1 \mathrm{H}), 2.95(\mathrm{t}, \mathrm{J}=8.1,2 \mathrm{H}), 2.73(\mathrm{t}, \mathrm{J}=8.1,2 \mathrm{H}), 1.53(\mathrm{~s}, 9 \mathrm{H}) ;{ }^{13} \mathrm{C} \mathrm{NMR}(125$ $\left.\mathrm{MHz}, \mathrm{CDCl}_{3}\right) \delta 152.7,147.8,146.5,138.4,136.5,134.7,129.1,128.2,127.8,125.4,124.0$, 117.5, 116.6, 80.9, 28.5, 28.3, 26.1; HRMS-ESI calcd for $\mathrm{C}_{21} \mathrm{H}_{22} \mathrm{O}_{4} \mathrm{~N}_{2} \mathrm{Na} 389.1471$, found $389.1473[\mathrm{M}+\mathrm{Na}]^{+}$.

\section{ASSOCIATED CONTENT}

Supporting Information ${ }^{1} \mathrm{H}$ and ${ }^{13} \mathrm{C}$ spectra of new compounds 4-8, 11, 12, 15-21, and 23 . UV and emission spectra of compounds 20 and 21. Computational details, optimized 
geometries, excited-state structures, and natural transition orbitals. This material is available free of charge via the Internet at http://pubs.acs.org.

\section{AUTHOR INFORMATION}

Corresponding Authors

*E-mail: mabe@hiroshima-u.ac.jp.*E-mail: claudine.katan@univ-rennes1.fr.

Notes

The authors declare no competing financial interest.

\section{ACKNOWLEDGMENTS}

NMR and MS measurements were performed at N-BARD, Hiroshima University. This work was partially supported by a Grant-in-Aid for Science Research on Innovative Areas "Stimuli-responsive Chemical Species" (No. 24109008), "pi- Space" (No. 21108516), and No. 19350021 from the Ministry of Education, Culture, Sports, Science and Technology, Japan, and by the Tokuyama Science Foundation. This work was granted access to the HPC resources of CINES and of IDRIS under the allocations 2013[x2013080649] made by GENCI (Grand Equipement National de Calcul Intensif).

\section{References and Notes}

(1) (a) Ellis-Davies, G. C. R. Beilstein J. Org. Chem. 2013, 9, 64-73. (b) Klán, P.; Solomek, T.; Bochet, C. G.; Blanc, A.; Givens, R.; Rubina, M.; Popik, V.; Kostikov, A.; Wirz, J. Chem. Rev. 2013, 113, 119- 191. (c) Yu, H.; Li, J.; Wu, D.; Qiu, Z.; Zhang, Y. Chem. Soc. Rev. 2010, 39, 464-473.

(2) (a) Parpura, V.; Basarsky, T. A.; Liu, F.; Jeftinija, K.; Jeftinija, S.; Haydon, P. G. Nature 1994, 369, 744-747. (b) Matsuzaki, M.; Hayama, T.; Kasai, H.; Ellis- Davies, G. C. R. Nature Chem. Bio. 2010, 6, 255 257.

(3) (a) Svoboda, K.; Yasuda, R. Neuron, 2006, 50, 823-839. (b) EllisDavies, G. C. R. Nat. Methods, 2007, 4, 619-628. (c) Sjulson, L.; Miesenböck, G. Chem. Rev. 2008, 108, 1588-1602. (d) Specht, A.; Bolze, F.; Omran, Z.; Nicoud, J.-F.; Goeldner, M. HFSP J. 2009, 3, 255 264. (e) Pawlicki, M.; Collins, H. A.; Denning, R. G.; Anderson, H. L. 
Angew. Chem., Int. Ed. 2009, 48, 3244-3266. (f) Warther, D.; Gug, S.; Specht, A.; Bolze, F.; Nicoud, J.- F.; Mourot, A.; Goeldner, M. Bioorg. Med. Chem. 2010, 18, 7753-7758. (g) Ellis-Davies, G. C. R. ACS Chem. Neurosci. 2011, 2, 185-197. (h) Bort, G.; Gallavardin, T.; Ogden, D.; Dalko, P. I. Angew. Chem., Int. Ed. 2013, 52, 4526-4537. (i) Olson, J. P.; Kwon, H. B.; Takasaki, K. T.; Chiu, C. Q.; Higley, M. J.; Sabatini, B. L.; Ellis-davies, G. C. R. J. Am. Chem. Soc. 2013, 135, 5954-5957. (j) Morales, A. R.; Frazer, A.; Woodward, A, W.; Ahn-White, H. Y.; Fonari, A.; Tongwa, P.; Tomofeeva, T.; Belfield, K. D. J. Org. Chem. 2013, 78, 1014-1025. (h) Terenziani F.; Katan C.; Badaeva E.; Tretiak S.; Blanchard-Desce M. Advanced Materials 2008, 20, 4641-4678.

(4) Two-photon uncaging cross-section is the important parameter for caged glutamates to measure their efficiency in releasing glutamate under photolysis conditions, it is the product of their 2PA cross section $\left({ }^{\mathrm{TM}} \mathrm{u}\right)$ and their uncaging quantum yield $\left(\sqrt{u}_{\mathrm{u}}\right)$

(5) Corrie, J. E.; DeSantis, A.; Katayama, Y.; Khodakhah, K.; Messenger, J. B.; Ogden, D. C.; Trentham, D. R. J. Physiol. 1993, 465, 1-8. (6) Wieboldt, R.; Gee, K. R.; Niu, L.; Ramesh, D.; Carpenter, B. K.; Hess, G. P. Proc. Natl. Acad. Sci. U. S. A. 1994, 91, 8752-8756.

(7) Göppert-Mayer (GM) unit: $1 \mathrm{GM}=10^{-50} \mathrm{~cm}^{4} \mathrm{~s}_{\text {photons }}{ }^{-1}$ molecule ${ }^{-1}$; named in honor of Maria Göppert-Mayer, who set the theoretical basis of the TPA process, see: (a) Gçppert-Mayer, M. Ann. Phys. 1931, 401, 273294. (8) (a) Furuta, T.; Wang, S. S. H.; Dantzker, J. L.; Dore, T. M.; Bybee, W. J.; Callaway, E. M.; Denk, W.; Tsien, R. Y. Proc. Natl. Acad. Sci. U.S.A. 1999, 96, 1193-1200. (b) Givens, R. S.; Rubina, M.; Wirz, J. Photochem. Photobiol. Sci. 2012, 11, 472-488.

(9) Matsuzaki, M.; Ellis-Davies, G. C. R.; Nemoto, T.; Miyashita, Y.; Iino, M.; Kasai, H. Nat. Neurosci. 2001, 4, 1086-1092. (b) G.

Papageorgiou, J. E. T. Corrie, Tetrahedron 2000, 56, 8197-8205; (c) Nikolenko, V.; Poskanzer, K. E.; Yuste, R. Nat. Methods 2007, 4, 943950. (10) Ellis-Davies, G. C. R.; Matsuzaki, M.; Paukert, M.; Kasai, H.; 
Bergles, D. E. J. Neurosci. 2007, 27, 6601-6604.

(11) (a) Gug, S.; Charon, S.; Specht, A.; Alarcon, K.; Ogden, D.; Zietz, B.; Léonard, J.; Haacke, S.; Bolze, F.; Nicoud, J.-F.; Goeldner, M. ChemBioChem 2008, 9, 1303-1307. (b) Donato, L.; Mourot, A.; Davenport, C. M.; Herbivo, C.; Wather, D.; Léonard, J.; Bolze, F.; Nicoud, J.-F.; Kramer, R. H.; Boeldner, M.; Specht, A. Angew. Chem., Int. Ed. 2012, 51, 1840-1843.

(12) (a) Fino, E.; Araya, R.; Peterka, D. S.; Salierno, M.; Etchenique, R.; Yuste, R. Front. Neural Circuits 2009, 3, 2. (b) Salierno, M.; Marceca, E.; Peterka, D. S.; Yuste, R.; Etchenique, R. J. Inorg. Biochem. 2010, $104,418-422$.

(13) Gug, S.; Bolze, F.; Specht, A.; Bourgogne, C.; Goeldner, M.; Nicoud, J.-F. Angew. Chem. 2008, 120, 9667-9671; Angew. Chem. Int. Ed. 2008, 47, 9525-9529. (b) Gug, S.; Charon, S.; Specht, A.; Alarcon, K.; Ogden, D.; Zietz, B.; Leonard, J.; Haacke, S.; Bolze, F.; Nicoud, J.F.; Goeldner, M. ChemBioChem 2008, 9, 1303-1307. (c) Picard, S.; Cueto-Diaz, E. J.; Genin, E.; Clermont, G.; Acher, F.; Ogden, D.; Blanchard-Desce, M. Chem. Commun. 2013, 49, 10805-10807.

(14) Sakamoto, Y.; Boinapally, S.; Katan, C.; Abe, M. Tetrahedron Lett. 2013, 54, 7171-7174.

(15) He, G. S.; Tan, L. S.; Zheng, Q.; Prasad, P. N. Chem. Rev. 2008, $108,1245-1330$.

(16) Albota, M.; Beljonne, D.; Bredas, J. L.; Ehrlich, J. E.; Fu, J. Y.; Heikal, A. A.; Hess, S. E.; Kogej, T.; Levin, M. D.; Marder, S. R.; McCord-Maughon, D.; Perry, J. W.; Rockel, H.; Rumi, M.; Subramaniam, G.; Webb, W. W.; Wu, X. L.; Xu, C. Science 1998, 281, 1653.

(17) Anderson, R. J. M.; Holtom, G. R.; McClain, W. M. J. Chem. Phys.1979, 70, 4310-4315. 
POST-PRINT: dx.doi.org/10.1021/jo501425p I J. Org. Chem. 2014, 79, 7822-7830

(18) Ghoneim, O. M.; Legere, J. A.; golbraikh, A.; Tropsha, A.; Booth, R. G. Bioorg. Med.Chem. 2006, 14, 6640-6658.

(19) Yin, J.; Buchwald, S. L. J. J. Am. Chem. Soc. 2002, 124, 60436048 .

(20) Miyaura, N.; Yanagi, T.; Suzuki, A. Synth. Commun. 1981, 11, 513.

(21) More, S. S.; Vince, R. J.Med. Chem. 2009, 52, 4650-4656.

(22) Wagner, P. J.; Kemppainen, A. E. J. Am. Chem. Soc. 1968, 90, 5896. 